Kocziszky György - Veresné Somosi Mariann

\title{
Közösségi tulajdonú (nem pénzügyi) gazdasági társaságok fenntarthatóságának vizsgálata
}

Összefoglaló: A közösségi tulajdonú - nem pénzügyi - gazdasági társaságok fontos szerepet töltenek be a fejlett országok gyakorlatával összhangban, hazánk gazdaságában, társadalmi, politikai közhangulatának formálásában. Ennek elsősorban az az oka, hogy olyan vállalatok (például egészségügy, közlekedés, energiaellátás, távfưtés, vízközmú-üzemeltetés stb.) vannak állami, illetve önkormányzati tulajdonban, amelyek stratégiai jelentőségǔek, szolgáltatásaik színvonalával, megbízhatóságával, árképzésével alapvetően befolyásolják a társadalmi közhangulatot. Ezért múködtetésük hatékonysága, vagyoni helyzetük, foglalkoztatási képességük, termelékenységük, tőkearányos eredményük közép- és hosszabb távú fenntarthatósága hatással van a társadalmi jóllétre. Ez a társadalmi érzékenység fokozott felelősséget ró egyrészt a közösségi tulajdonú vállalatok fenntartóira, tulajdonosi jogaik gyakorlóira másrészt a szervezetek menedzsmentjére. Ezért sem mindegy, hogy ezek a szervezetek hogyan, milyen feltételek mellett tarthatók fenn.

Tanulmányukban a szerzők (a témaválasztás indoklását követően) a következőkre keresik a választ. Hogyan definiálható a fenntartható közösségi vállalat? Milyen indikátorok segítségével és hogyan mérhető a közösségi vállalatok fenntarthatósága? Milyen következtetések vonhatók le a mutatók, részindexek, illetve az index változásából?

KuLcsszavaK: vállalati életgörbe, közösségi tulajdonú vállalat, kompozit-index, korai figyelmeztető rendszer

JEL-Kóook: L32, Q01

DOl: https://doi.org/10.35551/PSZ_2020_k_1_3

Indokolt-e az állam tulajdonosi szerepvállalása? Lehet-e jó tulajdonos az állam? Versenyképesebb-e és fenntarthatóbb-e a piaci alapon működő vállalkozás, mint az állami tulajdonban lévő?

Mind olyan kérdés, amit direkt és indirekt módon már a neoklasszikus közgazdaságtan

Levelezési e-cím: regkagye@uni-miskolc.hu művelői is felvetettek a 19. század második felében.

Az elmúlt évtizedekben a gazdaságpolitika kísérletet tett mind a két modell (a dirigista és az éjjeliőr állam) gyakorlatba történő átültetésére, de egyik sem váltotta be a hozzáfüzött reményeket. Sem a kizárólag piaci, sem pedig a centralizált állami tulajdon, illetve az azt szolgáló szabályozás hosszabb távon nem bizonyult fenntarthatónak. 
Ennek okait keresve (a teljesség igénye nélkül) a szakirodalom elsősorban arra utal, hogy az „államtalanított”, tiszta magángazdaság esetében egyrészt sérülnek a nemzeti és a közösségi (pl. igazságosság, a térbeli egyensúly stb.) érdekek (Hanka, 1982; Stor, 2001), másrészt fennáll a morál-hazárd (pl. stratégiai szempontból jelentős társaságokat még felelőtlen gazdálkodás esetében is kénytelen megmenteni az állam a csődtől, mert „túl nagy ahhoz, hogy csődbe mehessen” stb.) veszélye (Maggison, 2005). A kizárólagos állami tulajdonnak is számos kockázata van. Például csökkenhet a termelékenység, a gazdaságosság és a költségérzékenység a tulajdonosi szemlélet hiánya, vagy a szervezet monopol helyzete miatt, másrészt a gazdaság szívásos állapota következtében elmaradhatnak a szükséges fejlesztések, beruházások, elavulhatnak a termékek és a technológiák (Maggison, Jeffry, 2003; Savas, 1987). ${ }^{1}$

Nem véletlen, hogy ma már a szakirodalom sokkal inkább az optimális (vagy ahhoz közelítő) duális tulajdonosi struktúra kérdésével, nem pedig annak indokoltságával foglalkozik, különös tekintettel a makrogazdasági turbulenciák időszakában betöltött kiegyenlítő szerepükre, valamint a társadalmi jóllétre gyakorolt hatásukra. ${ }^{2}$

\section{A KÖZÖSSÉGI VÁLLALATOK MAKROGAZDASÁGI JELENTŐSÉGE}

A közösségi vállalatok a magyar gyakorlatban a központi kormányzat (állami) és a helyi önkormányzatok irányítása alatt álló gazdálkodó szervezetek, továbbá azok leányvállalatai. A magyar statisztika ezeket 2010-től (a vállalati szektoron belül) elkülönülten vizsgálja (MNB, 2019).

A közvetlen állami és önkormányzati tulajdonú vállalatok azonosítása évente, a társasági adóbevallásban szereplő jegyzett tőke tulajdonosi bontása alapján történik (leányvállalata- ik feltérképezéséhez a vállalatok éves beszámolóiban közölt információk adnak támpontot). A pénzügyi számlák a társasági adóbevallások és az éves beszámolók alapján készülnek. Kiegészítő adatszolgáltatások segítik, hogy az állományi adatok és az éves állományváltozások összetevői megfelelő részletezettséggel és pontossággal álljanak elö. ${ }^{3}$

Az elmúlt években (2010-2017) a közösségi vállalatok számában nem volt lényegi változás, számuk 2200 és 2300 között volt (a közösségi vállalati körbe be-, illetve onnan kikerülő szervezetek száma hozzávetőlegesen azonos volt). Nagyobb csökkenés a közösségi vállalatok számában 2017-ben következett be, amit elsősorban az önkormányzati tulajdonban lévő szervezetek nagyobb arányú megszűnése, és az új alapítású vállalatok számának visszaesése okozott. 2017 végén a közösségi vállalatok mintegy negyede volt állami tulajdonban, ez az arány a vizsgált időszakban szerény mértékben nőtt (MNB, 2019).

$\mathrm{Az}$ állami és önkormányzati vállalatok aránya alig több mint 10 százaléka az összes magyar vállalaténak, szemben az Európai Unió gyakorlatával, ahol ez az arány közel 20 százalékos. Indokolatlanok tehát azok az állítások, amelyek az állam túlzott reprivatizációs törekvéseire utalnak (Dietrich, 2012. p. 6; Schöneich, 2001.p. 7).

A vizsgált vállalati kör nagyságának megfelelő a hozzáadott értékek aránya, árbevétele, a reáleszközök és a mérlegföösszege (1. ábra). ${ }^{4}$

A közösségi tulajdonban lévő vállalkozások hozzáadott értéke azonban (az energetikai szektor kivételével) jóval alacsonyabb, mint a hasonló profilú magántulajdonban lévő társaiké (lásd 2. ábra).

A közösségi vállalatok (profiljuknak megfelelően) ugyanakkor jelentős foglalkoztatók valamennyi OECD-országban, így hazánkban is (lásd 3. ábra).

Összefoglalva aligha vitatható, hogy a vizsgált vállalati kör egyrészt foglalkoztatottsági, 


\section{A KÖZÖSSÉGI VÁLLALATOK RÉSZESEDÉSE}

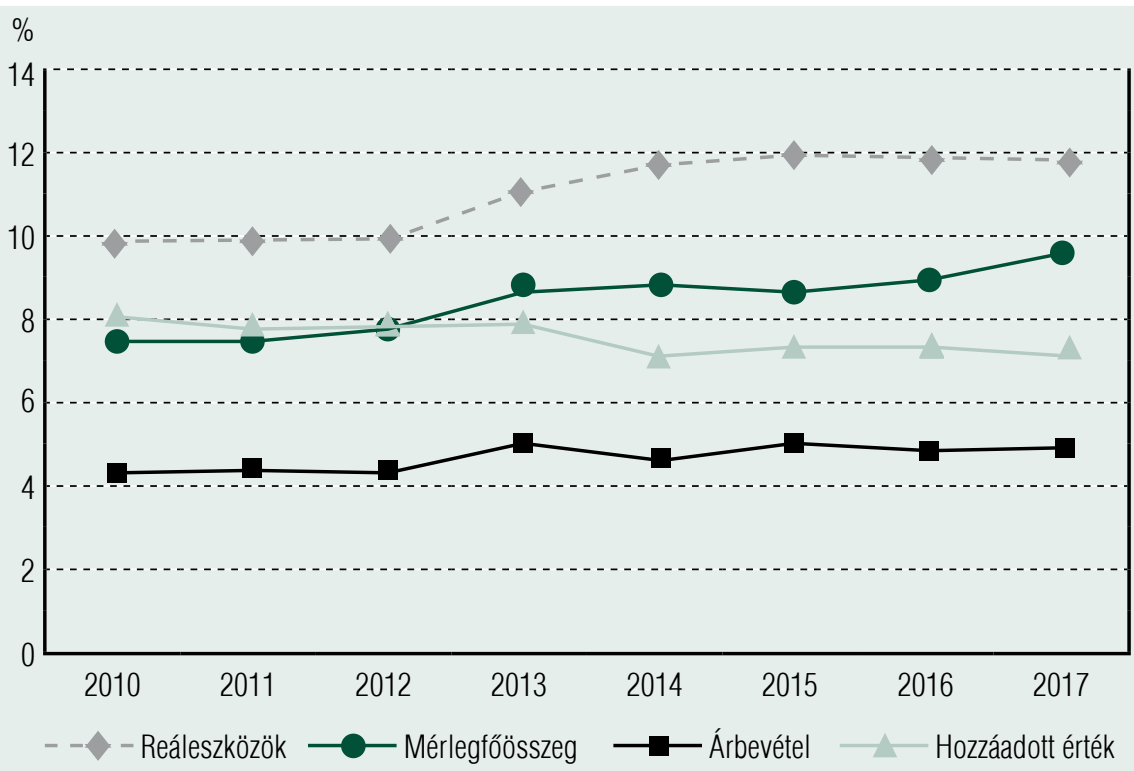

Forrás: MNB, pénzügyi számlák, közösségi vállalatok pénzügyi számlái alapján saját szerkesztés

2. ábra

\section{MAGYAR VÁLLALATOK HOZZÁADOTT ÉRTÉKÉNEK MEGOSZLÁSA AZ EGYES ÁGAZATOKBAN A VÉGSÓ TULAJDONOS SZERINT}

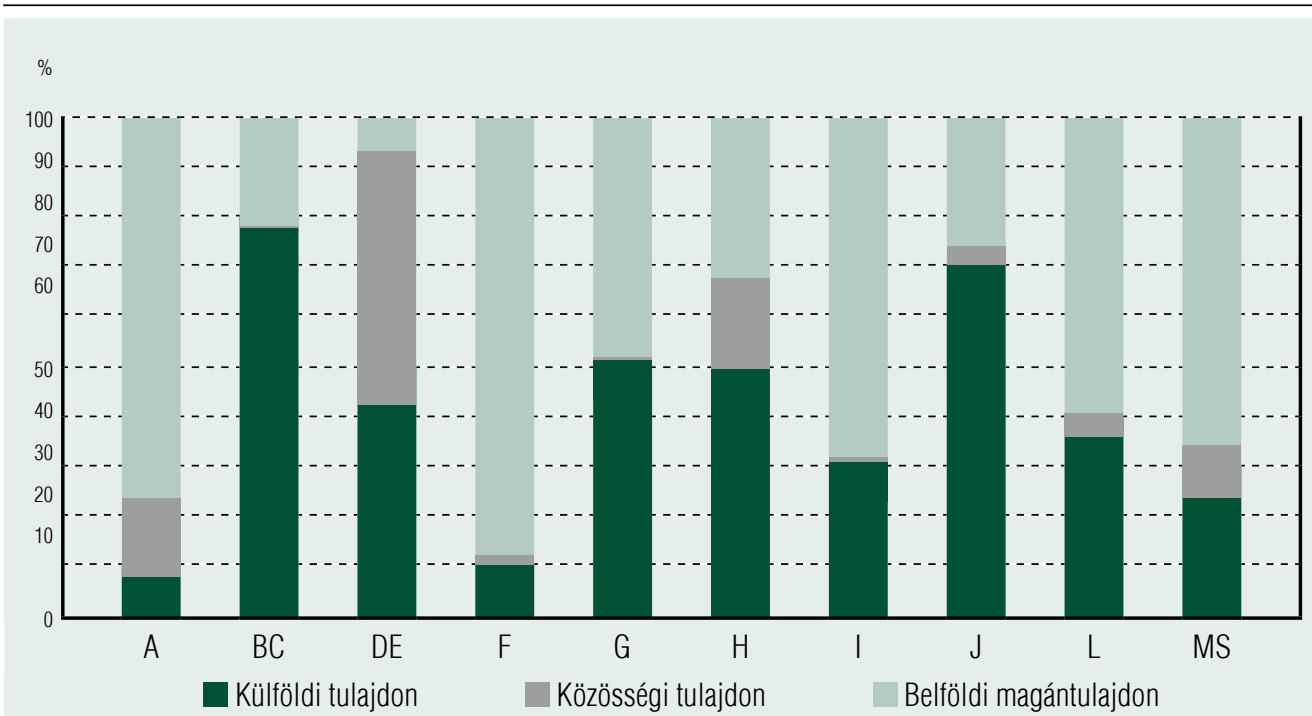

Jelmagyarázat: A: mezőgazdaság, BC: ipar, DE: energia, F: épitőiipar, G: kereskedelem, H: szállítás, I: szálláshely, J: információ, L: ingatlan, MS: egyéb

Forrás: MNB, statisztikai célú vállalati adatbázis. A 2017. évi adatok alapján saját szerkesztés 


\section{A KÖZSZOLGÁLTATÓ SZEKTOR FOGLALKOZTATÁSI SÚLYA}

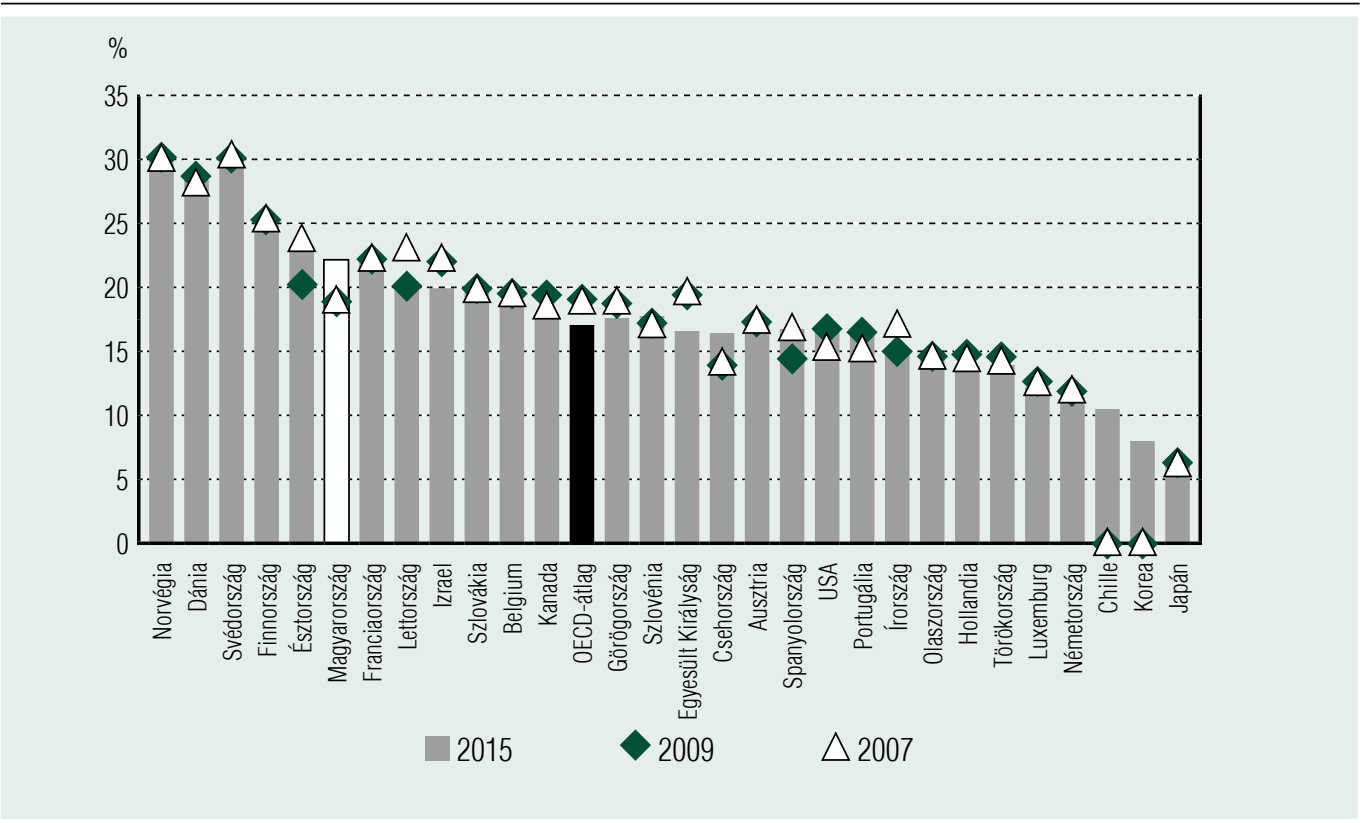

Forrás: Governmentat a Glance 2017 - C O OECD 2017

mind pedig árbevétel szempontból, másrészt funkcionális szempontból kiemelt odafigyelést igényel mind makro-, mind pedig mikrogazdasági szempontból.

\section{A FENNTARTHATÓ KÖZÖSSÉGI VÁLLALAT FOGALMA ÉS JELLEMZŐI}

A fenntarthatóság fogalma közel sem újszerű (Carson, 1962; Meadows et al., 1972; Brown, 1981). Az első tanulmányok szerzői elkülönülten, nem egyszer egymást kizáró (növekedés vs. fenntarthatóság) szemléletben, alapvetően ökológiai megközelítésben tárgyalták a fenntarthatóságot. ${ }^{5}$

Az elmúlt évtizedben a két eltérő (haszonés ökológiai szempontú) szemlélet közeledett egymáshoz, amit az ENSZ (United Nations, 2011; 2012; UNEP, 2011) és az egyes tagállamok jelentései egyaránt igazolnak. Másrészt az 1990-es évektől a fenntarthatóság értelmezését mezoszintre is kiterjesztették (pl. Bajmócy et al., 2012; Dirk, 2003).

A makro- (Rió, 1993; Kerekes, Jámbor, 2012; Szlávik, 2013) és mezoszintű (ÉMSZB, 2018; DU, 2004; Birkmann et al., 1999) fenntarthatóság vizsgálatához képest szerényebb múltra tekint vissza a vállalati fenntarthatóság vizsgálata. Ebben szerepe volt annak is, hogy a mainstraim szakirodalom az 1950es évektől elsősorban a vállalati növekedés kérdésével foglalkozik (Penrose, 1959), ami nem azonos a vállalati fenntarthatósággal (az utóbbi annál összetettebb fogalom).

A napjainkra végbement paradigmaváltás szerint a fenntartható vállalat egyidejűleg tesz eleget a társadalmi, az ökológiai és a gazdasági elvárásoknak; a fenntarthatóság e három tényező kiegyensúlyozott, stabil kölcsönhatását fejezi ki. ${ }^{6}$ Azaz a tulajdonosi elvárásokkal összhangban álló gazdasági elvárás (pl. alapte- 
vékenység bővülése, technológiai váltás stb.) nem járhat negatív természeti, környezeti hatásokkal (mert a természeti tőke csak részben helyettesíthető fizikai tőkével), illetve nem lehet ellentétben a társadalmi elvárásokkal (pl. szolgáltatás színvonala stb.).

Az ökológiai, a gazdasági és a társadalmi elvárások közötti interdependencia vizsgálata azért is releváns, mert a hagyományos, parciális szemlélet nehezíti az ökológiai és a társadalmi szempontok érvényesülését.

A fenntarthatóság nem független a vállalatok klasszikus életgörbe-elméletétől (Adizes, 1990; Kocziszky, 1994), optimális esetben az életgörbe kritikus (inflexiós) pontjához közeledve (ahol a müködés indikátorai beszakadnak) egy korai figyelmeztető rendszer hívhatja fel a figyelmet.

Érdemes különbséget tenni a fenntarthatóság (statikus állapot) és a fenntartható fejlődés (folyamat) között. Vizsgálataink során az utóbbit tartottuk (a vállalati életgörbék szempontjából) fontosnak. ${ }^{8}$ Azaz egy vállalat életgörbéje akkor tesz eleget a fenntartható fejlődés kritériumának, ha a fenntarthatóságot jellemző indikátorok eredőjének értéke (az alapítási, felfutási, eredményességi szakaszokat követően az öregedési, válságszakaszokkal szemben) nem csökken monoton módon.

A fenntartható vállalati fejlődés feltétele hosszú távú:

- értékorientált stratégiai gondolkodás,

- vagyongyarapodás, ${ }^{9}$

- környezettudatos magatartás,

- technológiai és szervezeti megújulás,

- értékorientált kompetenciafejlesztés.

A vállalatok fenntarthatóságával kapcsolatos vizsgálatoknak különös aktualitást ad az úgynevezett negyedik ipari forralom, ami új kihívások elé állítja a vállalatokat, illetve a menedzsmentet. Nem nehéz ugyanis megjósolni, hogy a digitalizáció komolyan hat a fenntarthatóságra is. Csak azok a társaságok tudnak megfelelni ennek a kihívásnak, amelyek ma- guk is képesek kielégíteni az intelligens vállalat (smart factoring) követelményeit (mint pl. magas termelékenység, hálózati együttműködés, digitalizáció, rugalmasság; Aier, Dogen, 2005. p. 610).

\section{FENNTARTHATÓSÁGI INDEX ÉRTELMEZÉSE}

Mindezek ismeretében jogos tulajdonosi és társadalmi igény a közösségi vállalatok fenntartható működésének és fejlődési lehetőségeinek vizsgálata, elemzése. Ezt hivatott segíteni a bemutatásra kerülő indikátormodellünk.

$\mathrm{Az}$ inputindikátorok a bemeneti feltételeket, az állapotindikátorok a müködés jellemzőit, míg az outputindikátorok a vállalkozás teljesítményére vonatkozó információkat szolgáltatják (4. ábra). ${ }^{10}$

$\mathrm{Az}$ inputindikátorok beállítását egyrészt gazdasági és társadalompolitikai szempontok, másrészt a fenntartónak (tulajdonosnak) az ágazatra vonatkozó jövőképe és stratégiája befolyásolja (5. ábra).

Az állapotindikátorokra (az inputok menynyiségi és minőségi jellemzői mellett) a vállalati menedzsment gyakorol hatást (6. ábra).

Az outputindikátorok a vállalat megújulási, értékteremtési képességét, a vagyoni és gazdálkodási helyzetét, továbbá a környezetre gyakorolt hatását jellemzik (7. ábra).

$\mathrm{Az}$ indikátorcsoportok meghatározásakor a vállalatgazdaságtani értelmezhetőségüket, a könnyü, gyors számszerűsíthetőségüket (azaz minimális többletteherrel járjon meghatározásuk), továbbá az ágazaton belüli összehasonlíthatóságot mérlegeltük.

A vizsgált mutatók rendszeres (évenkénti) számszerűsítése, a közöttük lévő kapcsolatok vizsgálata támogatja a vállalati vízió és stratégia kialakítását, illetve az eredmények monitorizálását egy-egy mutató kívánatos (célértékének) meghatározásával (8. ábra). 


\section{ÁLLAMI VÁLLALAT FENNTARTHATÓSÁGÁT BEFOLYÁSOLÓ INDIKÁTOROK}

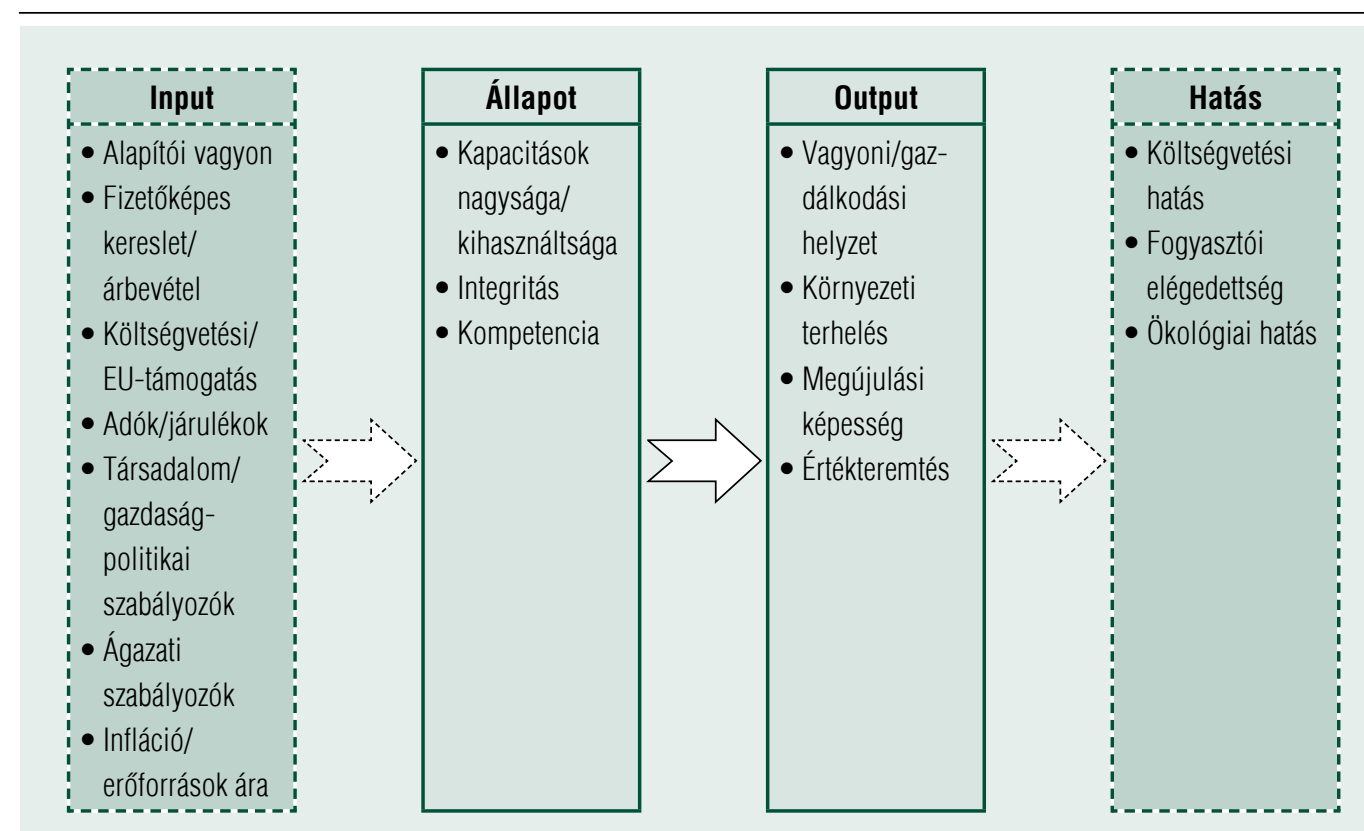

\section{INPUTINDIKÁTOROK VÁZLATOS HATÁSMECHANIZMUSA}

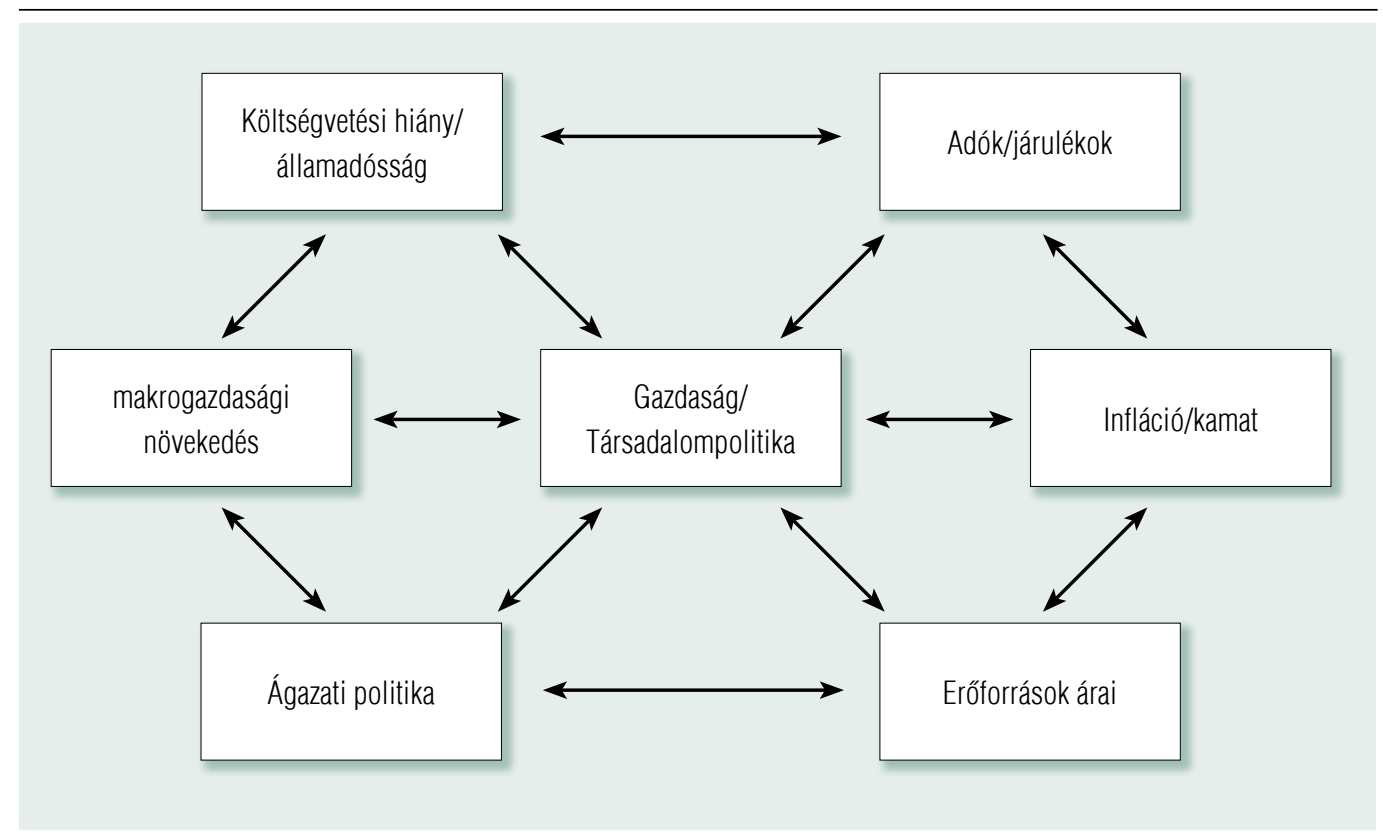




\section{ÁLLAPOTINDIKÁTOROK VÁZLATOS HATÁSMECHANIZMUSA}

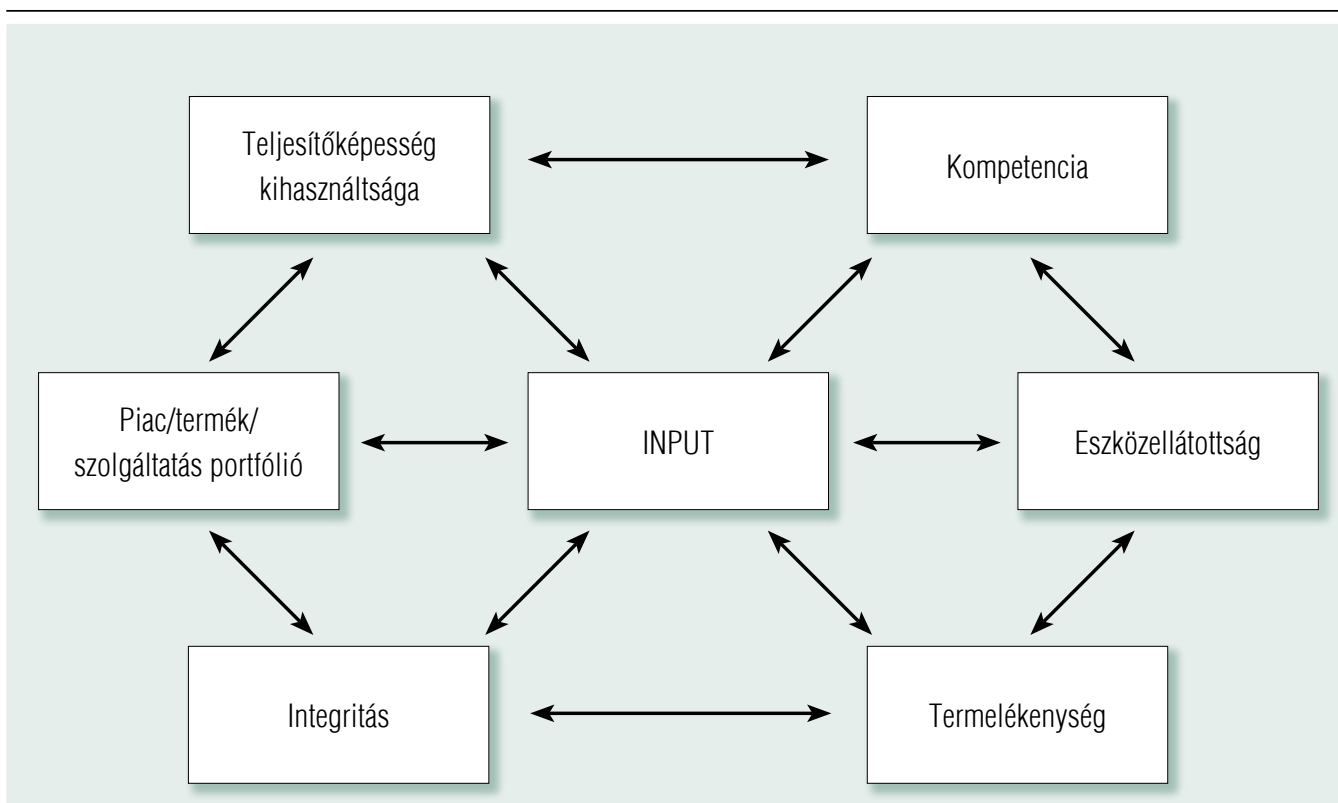

Forrás: saját szerkesztés

\section{OUTPUTINDIKÁTOROK VÁZLATOS HATÁSMECHANIZMUSA}

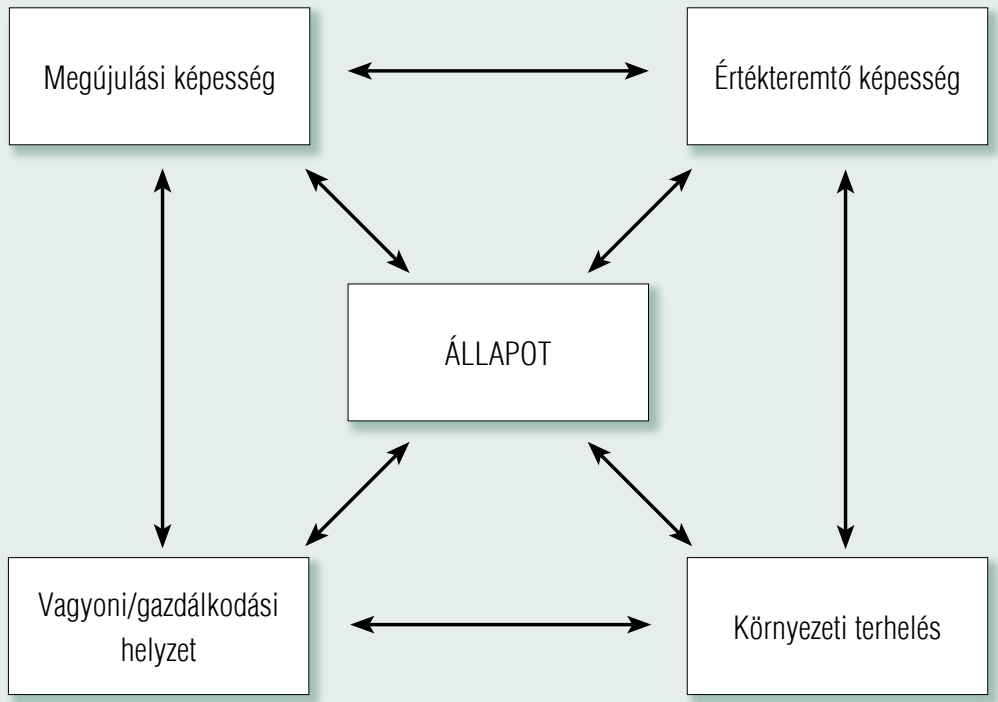

Forrás: saját szerkesztés 


\section{A MODELL INDIKÁTORAINAK KAPCSOLATA A VÁLLALATI VÍZIÓVAL/STRATÉGIÁVAL}

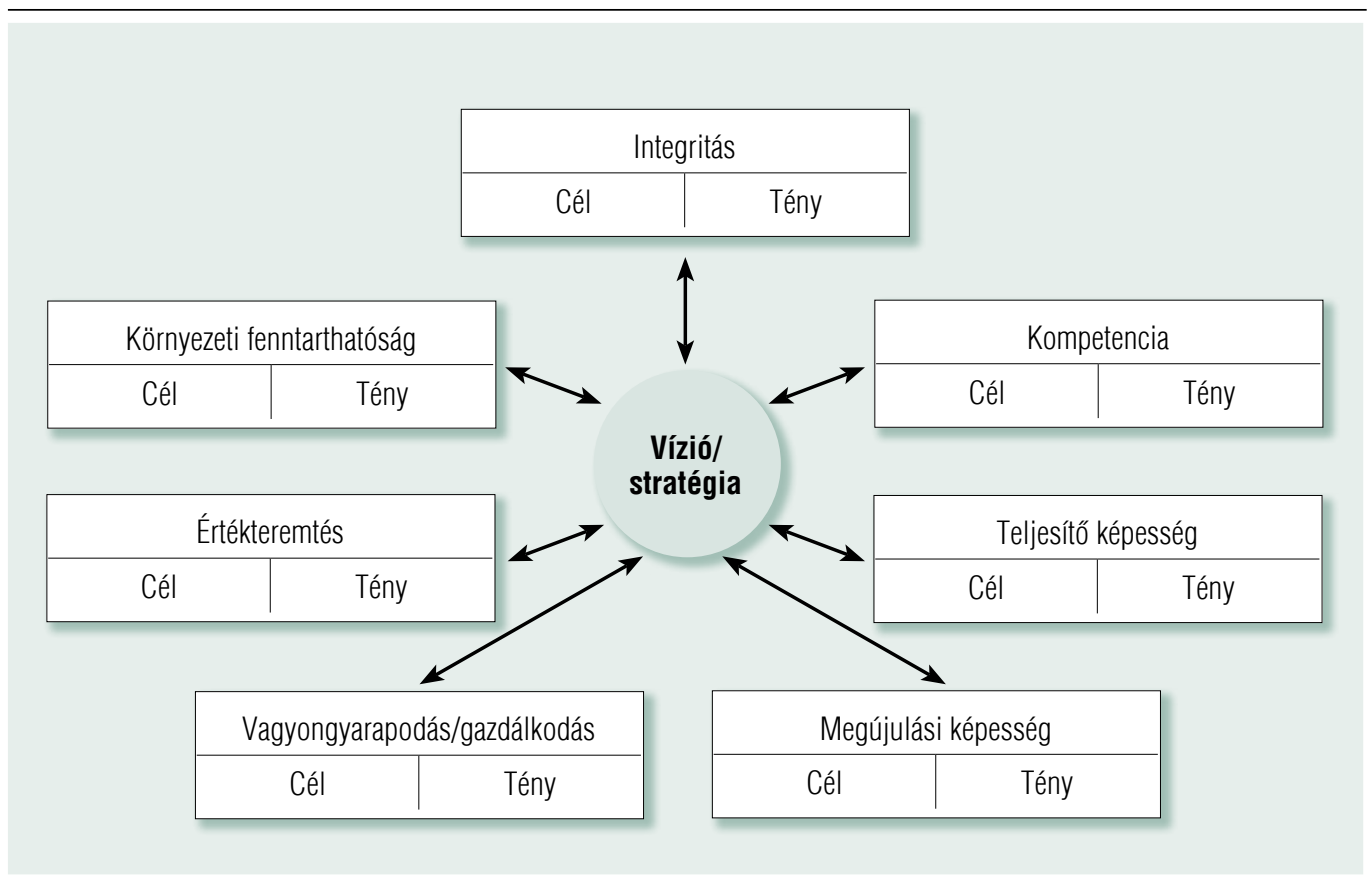

Forrás: saját szerkesztés

A vállalati menedzsmentnek a vállalati fenntarthatósággal kapcsolatos szabad mozgásterével összhangban három állapot- (integritás, kompetencia, teljesítmény/termelékenység) és négy outputindikátorát (megújulási képesség, értékteremtés, vagyongyarapodás/gazdálkodás, környezeti fenntarthatóság) vizsgáltuk. ${ }^{11}$

A mutatók jelentős részének (közel 75 százalékának) kidolgozása nem jelent az érintettek számára többletfeladatot, mert a Központi Statisztikai Hivatal, a Nemzeti Adó- és Vámhivatal, továbbá az Innovációs és Technológiai Minisztérium részére benyújtandó adatszolgáltatásokból kiolvashatók az adatok (1. táblázat).

A fenntarthatósági index (I) két részindex függvénye:

$I\left(t_{1}-t_{2}\right)=f\left[I I\left(t_{1}-t_{0}\right), K I\left(t_{1}-t_{0}\right), T I\left(t_{1}-t_{0}\right), M K\left(t_{1}-\right.\right.$ $\left.\left.t_{0}\right), E I\left(t_{1}-t_{0}\right), V I\left(t_{1}-t_{0}\right), K F\left(t_{1}-t_{0}\right)\right]$

\section{ÁLLAPOTINDIKÁTOROK}

Ennek keretében három állapotot leíró (integritási, kompetencia, teljesítmény) részindex, ezen belül hat mutató került definiálásra. A következőkben ezek számszerüsítésével kapcsolatos előzetes tapasztalatokat, illetve kockázatokat foglaljuk össze.

\section{Integritás részindex}

Az integritás index olyan kompozit mutató, amely az adott vállalat jogszerü, átlátható és etikus működését jellemzi.

A vállalati fenntarthatóság elemi feltétele az értékteremtés, ennek szükséges (de nem elégséges feltétele) a közjót szolgáló szabályszerű és etikus értékrend. Az amorális, a jogszabályokat és a közösség érdekeit sértő vállalati magatar- 


\section{MUTATÓKKAL KAPCSOLATOS ADATSZOLGÁLTATÁSI KÖTELEZETTSÉG}

\begin{tabular}{|c|c|c|c|}
\hline Ssz. & Részindex & Mutató & Adatszolgáltatás \\
\hline \multirow[t]{2}{*}{1.} & \multirow[t]{2}{*}{ Integritás-részindex } & Jogszabályi megfelelés & \multirow{2}{*}{$\begin{array}{l}\text { Önkéntes } \\
\text { (ÁSZ) }\end{array}$} \\
\hline & & Etikai megfelelés & \\
\hline \multirow[t]{2}{*}{2.} & \multirow[t]{2}{*}{ Kompetencia-részindex } & Egyéni kompetencia & \multirow[t]{2}{*}{ Saját felmérés/számítás } \\
\hline & & Szervezeti kompetencia & \\
\hline \multirow[t]{2}{*}{3.} & \multirow{2}{*}{$\begin{array}{l}\text { Teljesítóképesség/ } \\
\text { termelékenység-részindex }\end{array}$} & Időalap & \multirow[t]{2}{*}{ KSH } \\
\hline & & Teljesítmény norma & \\
\hline \multirow[t]{3}{*}{4.} & \multirow[t]{3}{*}{ Megújulási képesség részindex } & Technikai/technológiai megújulás & EU-projekt esetében (ITM) kötelező \\
\hline & & Kínálati portfólió megúijulás & $\begin{array}{l}\text { Kötelező } \\
\text { (KSH) }\end{array}$ \\
\hline & & Szervezeti, irányítási megújulás & Saját felmérés/számítás \\
\hline \multirow[t]{2}{*}{5.} & \multirow[t]{2}{*}{ Értékteremtési részindexindex } & Minőség, megbízhatóság & Önkéntes \\
\hline & & Hozzáadott érték & Kötelező (KSH) \\
\hline \multirow[t]{4}{*}{6.} & \multirow{4}{*}{$\begin{array}{l}\text { Vagyongyarapodási/gazdálkodási } \\
\text { részindex }\end{array}$} & Tőkehatékonyság & \multirow{4}{*}{$\begin{array}{l}\text { Kötelező } \\
\text { (KSH) }\end{array}$} \\
\hline & & Eszközhatékonyság & \\
\hline & & Likviditás & \\
\hline & & Hozzáadott érték & \\
\hline \multirow[t]{3}{*}{7.} & \multirow{3}{*}{$\begin{array}{l}\text { Környezeti fenntarthatósági } \\
\text { részindex }\end{array}$} & Fajlagos vízfelhasználás & \multirow{3}{*}{$\begin{array}{l}\text { Kötelező } \\
\text { (NAV) }\end{array}$} \\
\hline & & Fajlagos energiafelhasználás & \\
\hline & & Fajlagos károsanyag-felhasználás & \\
\hline
\end{tabular}

Forrás: saját szerkesztés

tás, az „ügyeskedés, a korrupció, előbb-utóbb negatív hatással van a vállalati eredményre, a vagyonra és a hitelképességre (lásd 9. ábra).

\section{Jogszabályi megfelelés}

A jogszabályi és szabályozottsági megfelelés követelménye, az Állami Számvevőszék ellenőrzési, tanácsadói tevékenységének, valamint az ellenőrzéseihez kapcsolódó „jó gyakorlat” konferenciáknak köszönhetően nem ismeretlen. ${ }^{12}$

A mutató meghatározását 15 kérdésből álló (lényegében az ÁSZ gyakorlatánál egyszerűbb) kérdőív segítségével javasoljuk (lásd 2. táblá- zat). A kérdésekre binális (igen vagy nem) válaszok adhatók, amelyek értékelése kétfokozatú (0 és 5) értékskálán végezhető el. A kérdőív kitöltéséért felelőst a vállalat első számú vezetőjének kell kijelölnie. A mutató estében célszerű meghatározni az elvárt pontszámot („csengető értéket”).

A jogszabályi és szabályozottsági megfelelés vizsgálata kapcsán kockázatot jelenthet, hogy az érintett szervezet kedvezőbb képet kíván magáról adni, mint a valóságos, továbbá a kérdőívet kitöltő nincs teljesen tisztában az aktuális jogszabályi elvárásokkal, így válaszai is pontatlanok. 


\section{JOGSZABÁLYI ÉS ETIKAI VÉTSÉGEK POTENCIÁLIS HATÁSLÁNCA}

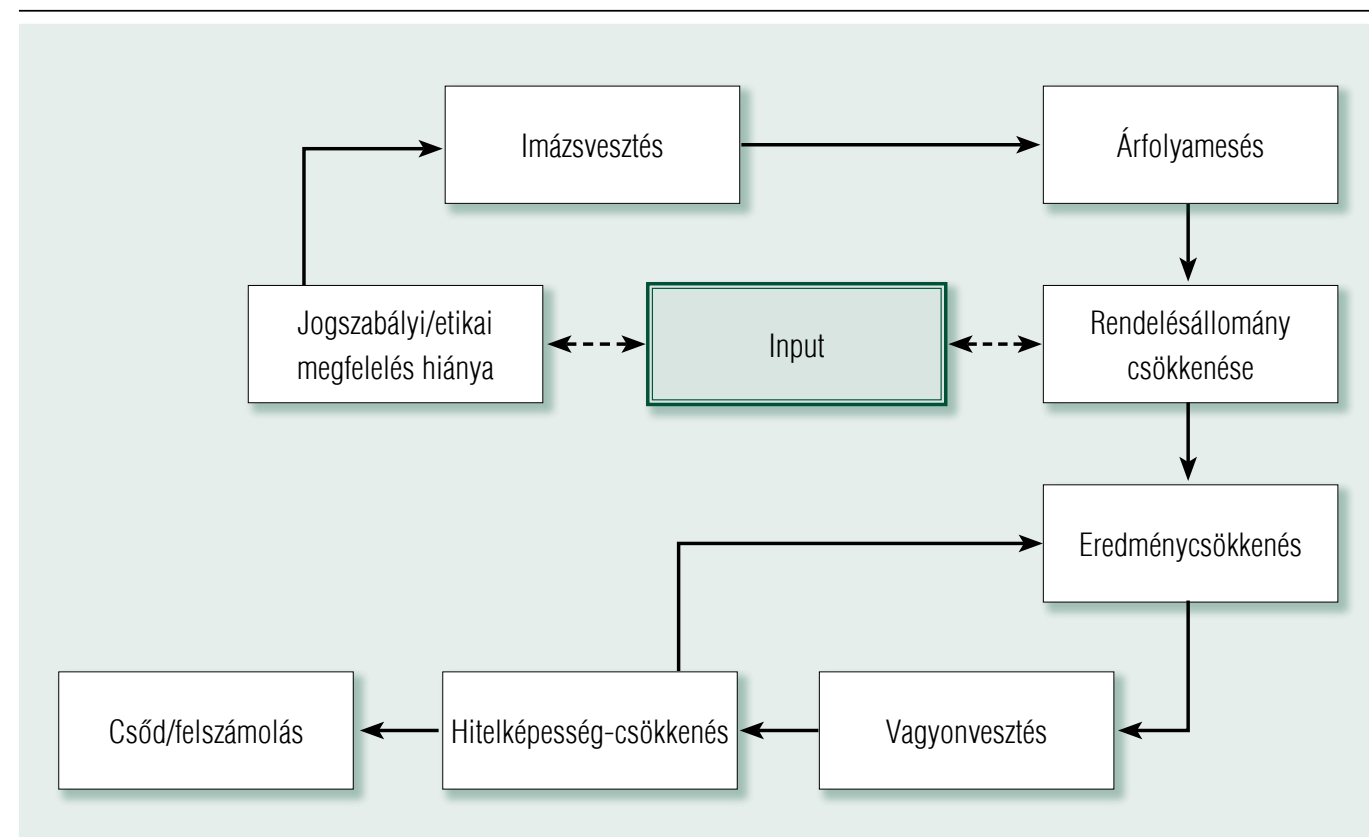

Forrás: saját szerkesztés

2. táblázat

\section{A SZABÁLYOZOTTSÁG VIZSGÁLATÁRA IRÁNYULÓ KÉRDÖÍV}

\section{Minősítés}

$0 \quad 5$

\section{Minösítés alapja}

SzMSz mellékletében rögzített jogszabályok

EU-rendelet adaptációja

2. Az előállított termékek/szolgáltatások esetében alkalmazzák is az EU piacfelügyeleti keretrendszerének elöirásait?

3. Rendelkezik a vállalat adatkezelési szabályzattal?

Adatkezelési szabályzat

4. A vállalat teljeskörüen megfelel az adatkezelésre vonatkozó (GDPR) Kommunikációs előirásoknak? szabályzat

5. Rendszeresen karbantartják a társaság szervezeti és múködési

SzMSz szabályzatát?

6. Rendszeresen karbantartja a társaság kockázatkezelési szabályzatát?

Kockázatkezelési

szabályzat

7. Rendelkezik a társaság közbeszerzési szabályzattal? 


\begin{tabular}{|c|c|c|c|c|}
\hline \multirow{2}{*}{ Ssz. } & \multirow{2}{*}{ Kérdés } & \multicolumn{2}{|c|}{ Minősítés } & \multirow{2}{*}{ Minő́sítés alapja } \\
\hline & & 0 & 5 & \\
\hline 8. & Rendelkezik a társaság külső kommunikációs szabályzattal? & & & $\begin{array}{l}\text { Kommunikációs } \\
\text { szabályzat }\end{array}$ \\
\hline 9. & $\begin{array}{l}\text { Rendelkezik a társaság a használaton kívüli vagyontárgyak értékesítési } \\
\text { szabályzatával? }\end{array}$ & & & Elidegenítési szabályzat \\
\hline 10. & Rendelkezik a társaság adatbiztonsági szabályzattal? & & & $\begin{array}{l}\text { Adatbiztonsági } \\
\text { szabályzat }\end{array}$ \\
\hline 11. & Teljeskörűen szabályozták a vállalati eszközök használatát? & & & $\begin{array}{l}\text { Eszközhasználati } \\
\text { szabályzat }\end{array}$ \\
\hline 12. & Szabályozták a döntések delegálásának elveit? & & & SzMSz \\
\hline 13. & Teljeskörúen szabályozták a javadalmazási elveket? & & & Kollektív szerződés \\
\hline 14. & A szabályzatok az érintettek számára hozzáférhetők az interneten? & & & Manuális ellenőrzés \\
\hline 15. & Rendelkezik a társaság compliance szakemberrel/szervezettel? & & & SzMSz \\
\hline \multicolumn{2}{|c|}{ Összesen: } & & & \\
\hline \multicolumn{2}{|c|}{ Elérhető pontszám } & \multicolumn{2}{|c|}{75 pont } & \\
\hline
\end{tabular}

Forrás: saját szerkesztés

\section{Etikai megfelelés}

Az etikai, illetve az integritási kockázatok felmérése a potenciális vállalati kör esetében (köszönhetően az Állami Számvevőszék ellenőrzéseinek) több éves múltra tekint vissza. Így az integritás fogalma, a belső kontrollok jelentősége nem újszerü az érintett vállalatvezetői körben (Domokos, 2015).

$\mathrm{Az}$ etikai megfelelés vizsgálatára tizenkét kérdésből álló kérdőív, illetve kitöltési útmutató szolgál. A kérdésekre igen/nem válasz adható (3. táblázat). A kérdőív kitöltéséért (az előbbiekhez hasonlóan) a vállalat első számú vezetője által kijelölt személy (pl. az etikai bizottság vezetője) a felelős.

A mutató meghatározásával, értékelésével kapcsolatos kockázatok:

- a felmérés szubjektív, fennáll annak a kockázata, hogy az adatközlő szervezet a ténylegesnél kedvezőbb képet kíván adni belső kontrollrendszerének működéséről;

- ez a kockázat valószínűleg nem szüntethető meg teljesen, de szúrópróbaszerű ellen- őrzéssel, továbbá az Állami Számvevőszék ellenőrzéseivel, illetve szükség esetén személyi felelősségre vonással csökkenthető.

\section{Kompetencia-részindex}

A tudásnak, a tudástőkének és annak feltételéül szolgáló kompetenciának egyre nagyobb szerepe van a vállalatok működésében, fenntarthatóságában.

A kompetencia, ami készségek, képességek, adottságok összessége, egyéni és szervezeti szinten egyaránt mérhetők, az index ezt kívánja számszerűsíteni. ${ }^{13} \mathrm{~A}$ vállalati fenntarthatóság feltétele a megújulás, amelynek végrehajtása személyi és szervezeti kompetenciákhoz kapcsolódik (10. ábra).

A technikai, technológiai változásokból származó kompetencia gap feltárása és felszámolása vállalati érdek. ${ }^{14}$

\section{Egyéni kompetencia}

$\mathrm{Az}$ egyéni kompetencia azon képességek és készségek összessége, amelyek az adott személy 


\section{ETIKAI MEGFELELÉS VIZSGÁLATÁRA SZOLGÁLÓ KÉRDŌíV}

\begin{tabular}{|c|c|c|c|c|}
\hline \multirow{2}{*}{ Ssz. } & \multirow{2}{*}{ Kérdés } & \multicolumn{2}{|c|}{ Minösítés } & \multirow{2}{*}{ Minősítés alapja } \\
\hline & & 0 & 5 & \\
\hline 1. & Rendelkezik a társaság etikai szabályzattal? & & & $\begin{array}{l}\text { Érvényben lévő etikai } \\
\text { szabályzat }\end{array}$ \\
\hline 2. & Vannak a társaságnál etikai tréningek? & & & $\begin{array}{l}\text { Éves rendszerességű } \\
\text { etikai tréning }\end{array}$ \\
\hline 3. & $\begin{array}{l}\text { Az etikai szabályzat összhangban van a társaság küldetési } \\
\text { nyilatkozatával }\end{array}$ & & & $\begin{array}{l}\text { Vállalat } \\
\text { küldetésnyilatkozata }\end{array}$ \\
\hline 4. & Az etikai szabályzat rögzíti, hogy mit tekintenek korrupciónak? & & & Etikai szabályzat \\
\hline 5. & Az etikai szabályzat pontosan rögzíti az üzleti ajándék fogalmát? & & & Etikai szabályzat \\
\hline 6. & Évente felülvizsgálják a társaság etikai szabályzatát? & & & $\begin{array}{l}\text { Etikai szabályzat } \\
\text { felülvizsgálatának } \\
\text { szabályozása }\end{array}$ \\
\hline 7. & $\begin{array}{l}\text { Rögzíti az etikai szabályzat az ügyfelekkel kapcsolatos viselkedési } \\
\text { normáikat? }\end{array}$ & & & Etikai szabályzat \\
\hline 8. & $\begin{array}{l}\text { Rögzíti az etikai szabályzat a munkatársak egymás közötti viselkedési } \\
\text { normáit? }\end{array}$ & & & Etikai szabályzat \\
\hline 9. & $\begin{array}{l}\text { Rögzíti az etikai szabályzat, hogy mit értenek összeférhetetlenség } \\
\text { alatt? }\end{array}$ & & & Etikai szabályzat \\
\hline 10. & Rögzíti az etikai szabályzat, hogy mit jelent az üzleti titok? & & & Etikai szabályzat \\
\hline 11. & Múködik a társaságnál etikai bizottság? & & & SzMSz \\
\hline 12. & Rögzíti az etikai szabályzat a diszkriminációmentességet? & & & Etikai szabályzat \\
\hline \multicolumn{2}{|c|}{ Összesen: } & & & \\
\hline \multicolumn{2}{|c|}{ Elérhető pontszám: } & \multicolumn{2}{|c|}{60 pont } & \\
\hline
\end{tabular}

Forrás: saját szerkesztés

tudását, tapasztalatát fejezi ki és adott munkakör betöltésére alkalmassá tesz. ${ }^{15}$ Azaz magába foglalja a tudást, tapasztalatokat és a személyi adottságokat. ${ }^{16}$

Vannak az egyéni kompetenciamérésnek hazai tapasztalatai, de ezeket többnyire az alapés középfokú iskolai oktatásban alkalmazzák a tanulók ismereteinek felmérésére.
Gazdálkodó egységek munkatársaira vonatkozó kompetenciafelmérések (szemben a fejlett országok gyakorlatával) hazánkban eseti jellegüek, nincs egységes gyakorlata, illetve módszertana. Ugyanakkor mérésére az egyéni teljesítményértékelésekhez kapcsolódóan egyre nagyobb szükség van.

Az egyéni kompetencia mérésére kidolgozott 


\section{A KOMPETENCIAHIÁNY POTENCIÁLIS HATÁSLÁNCA}

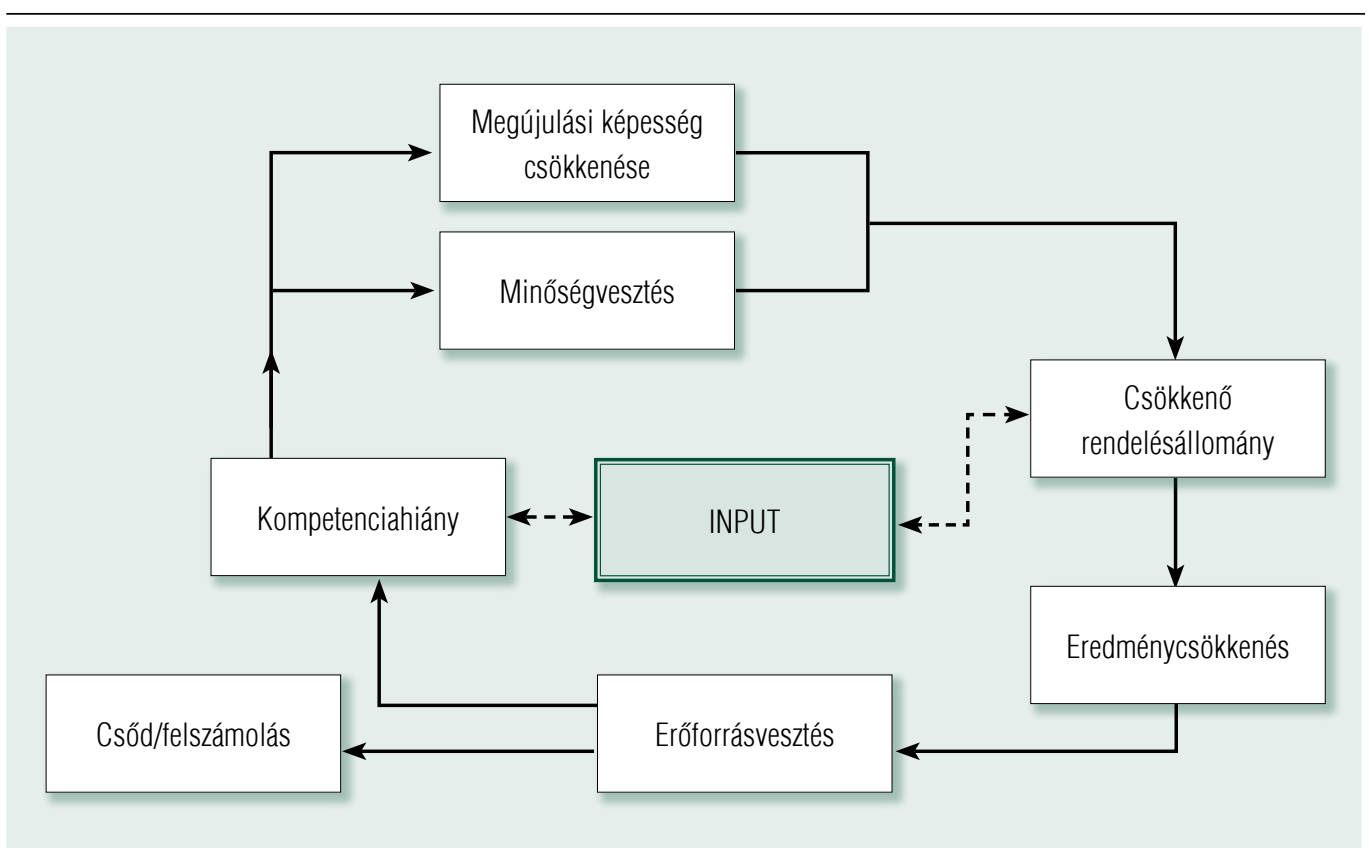

Forrás: saját szerkesztés

15 kérdést tartalmazó kérdőív háromfokozatú $(1,3,5)$ minősítésre ad lehetőséget (4. táblázat).

A kérdőív kapcsán személyenként (pl. életkortól, iskolai végzettségtől stb. függően) is meghatározható az elvárt minimális pontszám.

Az egyéni kompetenciamérések elsősorban az érintettek (munkavállaló, közvetlen munkahelyi vezető, humánvezető) érdekeit szolgálja, ezért bizalmasan kezelendő információ.

Célja az erősségek és a deficitek feltárása, az utóbbi megszüntetésére irányuló egyéni és szervezett formában történő képzési tervek/ programok összeállítása. A kérdőíveket egyrészt az érintetteknek, másrészt az adott munkatárs közvetlen munkahelyi vezetőjének kell kitöltenie. A kettő összevetése alapján állítható össze a személyes kompetenciafejlesztési terv (Veresné, 2005).

Az egyéni kompetenciák mérésével kapcsolatosan több irányú kockázattal lehet számolni, így például:
- az egyes kompetenciák megítélése szubjektív,

• az egyén, önös érdekből kedvezőbb képet kíván magáról adni, mint amilyen kompetenciákkal rendelkezik,

- a kompetenciák felmérését követően nem készül a munkavállalóra szabott kompetenciafejlesztési javaslat, vagy ha készül is, annak realizálását a munkaadó nem támogatja,

- a munkavállalónak hiányzik az ambíciója kompetenciája fejlesztésére,

- a munkahelyi vezető (önös érdekből) kedvezőtlenebb képet kíván a munkatársáról adni, mint azt a valóság indokolja.

\section{Szervezeti kompetencia mutatója}

A vállalat adott szervezetének alkalmassága adott feladatcsoport ellátására: elvárt ismeretek, készségek, jártasságok, magatartásnormák összessége a szervezetre vonatkozó feladat- 


\section{PÉLDA AZ EGYÉNI KOMPETENCIA MÉRÉSÉRE}

\begin{tabular}{|c|c|c|c|c|}
\hline \multirow{2}{*}{ Ssz. } & \multirow{2}{*}{ Minösítési szempont } & \multicolumn{3}{|c|}{ Minö́sítés } \\
\hline & & 1 & 3 & 5 \\
\hline
\end{tabular}

1. Konfliktuskezelési készség

2. Folyamatos tanulás

3. Viselkedési normák betartásának képessége

4. Problémamegoldó képesség

5. Szakmai (gyakorlati) jártasság

6. Önálló munkavégzés, döntési képesség

7. Felelősségtudat, megbízhatóság

8. Munkafegyelem

9. Kezdeményezőképesség

10. Teljesítmény

11. Ügyfél-, partnerorientáltság

12. Kitartás

13. Költségérzékenység

14. Digitális kompetencia

15. Módszertani kompetencia

Elért összes pontszám:

Elérhető pontszám*:

75 pont

Megjegyzés: A kérdések minősitése pontozással történik a következők szerint: 1 - elégtelen, 3 - közepes, 5 - jó.

Forrás: saját szerkesztés

körök minőségi ellátása érdekében (OECD, 2013).

A szervezeti szintű kompetencia mérésére vonatkozó hazai tapasztalatok viszonylag szerények ( ha vannak is, azokat üzleti titokként kezelik) annak ellenére, hogy ma már több tanácsadó szervezet ajánlja ilyen jellegű szolgáltatását.

Ezzel szemben az erre vonatkozó nemzetközi gyakorlat gazdag, integráns része lett a humán erőforrás- és a teljesítménymenedzsment rendszernek. ${ }^{17}$
A szerény hazai tapasztalatok miatt a felmérés fokozottabb előkészítést, körültekintést igényel. A szervezeti (csoport, osztály, stb.) kompetencia mérésének egyrészt az adott egység, másrészt a szervezeti egységet irányító közvetlen vezető feladat-, hatás- és felelősségi körének megfelelően specifikált szempontok alapján kell történnie.

Módszerünk alkalmazhatóságát a humánerőforrás-osztály kapcsán vizsgáltuk. A felmérés alapjául szolgáló kérdőív 11 kérdést tartalmaz (5. táblázat). 
5. táblázat

\section{PÉLDA HUMÁNERŐFORRÁS-OSZTÁLY SZERVEZETI KOMPETENCIÁJÁNAK EREDMÉNYÉRE}

\begin{tabular}{|c|c|c|c|c|}
\hline \multirow{2}{*}{ Ssz. } & \multirow{2}{*}{ Minösítési szempont } & \multicolumn{3}{|c|}{ Minösítés } \\
\hline & & 1 & 3 & 5 \\
\hline
\end{tabular}

1. Biztosítottak a szervezet értékteremtő folyamatainak inputjai?

2. Biztosítottak a koordinációs minták, rutinok a hatékony erőforrás felhasználáshoz?

3. Megfelelő a tudás, ismeret, amely meghatározza az erőcsoportok interakcióit?

4. Adottak a munkatársak tevékenységre való testi-lelki adottságai?

5. Megfelelő a nem anyagi erőforrásokkal való gazdálkodás (innováció, hírnév stb.)?

6. Megfelelően múködik a tudásmenedzselési rendszer a szervezetben?

7. A szervezeti tanulás fontos eleme a múködésnek?

8. Megvalósul a felsővezetés által hozzáadott érték a múködésben?

9. Redundáns hierarchia nehezíti-e a szervezet múködését?

10. Az alkalmazott technológia megfelel a kor elvárásának?

11. A szervezeti kultúra mennyiben támogatja az egyes kreatív megoldások kialakulását?

Elért összes pontszám:

Elérhetô pontszám*:

55 pont

Megjegyzés: 1 - elégtelen, 3 - közepes, 5 - jó

Forrás: saját szerkesztés

Minden szervezeti egység esetében külön is rögzíthető egy elvárt pontszám, a százalékos eredmény alapján összehasonlíthatók a szervezeti egységek eredményei (6. táblázat).

A kompetenciaalapú szervezeti struktúra (tapasztalataink szerint) relatíve új fogalom a hazai vállalati gyakorlatban. Ezért szerények az erre vonatkozó gyakorlati tapasztalatok, ami az ilyen típusú felmérések kockázatát is érinthetik, így például számolni lehet a felmérés kapcsán:

- az érintett szervezet, illetve a szervezet vezetőjének ellenállásával, az eredmények „kozmetikázásával”,
- a felméréshez kapcsolódóan nem készül a szervezetre vonatkozó kompetenciafejlesztési terv, vagy ha készül is, azt az érintettek formálisnak tekintik.

\section{Teljesitöképesség/termelékenység részindex}

Egy vállalat kapacitása adott mértékegységben kifejezett termék/szolgáltatási mennyiség, amely adott eszközállománnyal, adott idő (napok, müszakok) alatt, adott műszaki, szervezési és termékösszetétel mellett állítható elö. A kapacitás a legkedvezőbb adatokkal (veszteség és havária nélküli optimális idővel) számol. $^{18}$ 


\section{PÉLDA SZERVEZETI EGYSÉGEK KOMPETENCIÁJÁNAK ÖSSZEHASONLÍTÁSÁRA}

\begin{tabular}{|c|c|c|c|c|c|c|c|c|c|c|c|}
\hline \multirow{2}{*}{ Ssz. } & \multirow{2}{*}{$\begin{array}{l}\text { Szervezeti egység } \\
\text { megnevezése }\end{array}$} & \multicolumn{10}{|c|}{ Kompetenciaszint (\%) } \\
\hline & & 10 & 20 & 30 & 40 & 50 & 60 & 70 & 80 & 90 & 100 \\
\hline 1. & Humánpolitika & & & & $*$ & & & & & & \\
\hline 2. & Pénzügy & & & & & & & & & & \\
\hline 3. & Számvitel & & & & & & & & & & \\
\hline 4. & Technológia & & & & & & & & & & \\
\hline 5. & Minőségbiztosítás & & & & & & & & & & \\
\hline 6. & Termelés & & & & & & & & & & \\
\hline 7. & Szállítás/logisztika & & & & & & & & & & \\
\hline 8. & Controlling & & & & & & & & & & \\
\hline 9. & Jog & & & & & & & & & & \\
\hline 10. & Környezetvédelem & & & & & & & 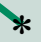 & & & \\
\hline
\end{tabular}

Forrás: saját szerkesztés

Az átbocsátóképesség a vizsgált időszakban megvalósuló reális teljesítmény, amely nagyobb kieső idő figyelembevételével határozható meg.

A kapacitás-, illetve teljesítőképesség, a szűk keresztmetszetek meghatározása alapvető üzemgazdasági ismeret, ezért minden esetben elvárt (elvárható) a meghatározásához szükséges tudás, illetve adatok ismerete. A vállalat meghatározott rendszerességgel ezen túlmenően köteles kapacitásadatokat szolgáltatni a $\mathrm{KSH}$ részére.

A vállalat termelőberendezéseinek kihasználtsága a tervezett és tényleges átbocsátóképesség hányadosa alapján határozható meg (7. táblázat).

A tervezett átbocsátó képesség $=[($ munkarend szerinti idöalap (óralév) $\times$ munkanapok száma $\times$ tényleges müszakszám $\times$ homogén gépek száma) - tervezett megelözö kapacitás óraigénye].
A teljesítőképesség-kihasználtság számításakor az alábbi kockázatokkal lehet számolni:

- az átbocsátóképesség-norma közelítő pontosságú, az úgynevezett vezértermékben történő számítás miatt,

- az időalap meghatározásakor a ténylegesen felmerülőknél nagyobb kieső időkkel számolnak a „tervalku” érdekében.

Aggregált mutató, a három tényező súlyozott számtani átlaga alapján határozható meg az kövekezők szerint:

Aggregált állapotindex $=0,3 \times[$ (jogszabá-

lyi megfelelés + etikai megfelelés + szervezeti kompetencia $)] / 3+(0,7 \times$ teljesitöképesség kihasználtsága).

A teljesítőképesség-kihasználtság nagyobb súllyal történő szerepeltetését az outputra gyakorolt nagyobb hatás indokolja. 


\section{A TELJESÍTMÉNYKIHASZNÁLTSÁG ÖSSZETEVŐI}

\begin{tabular}{|c|c|c|c|}
\hline Ssz. & Megnevezés & Számszerísítés & Adatok forrása \\
\hline 1. & Tényleges átbocsátóképesség & $\begin{array}{l}\text { (havária helyzetekkel csökkentett tényleges } \\
\text { időalap/veszteségekkel megnövelt norma) }\end{array}$ & Technikai/technológiai adatok \\
\hline 2. & Termelékenység & Nettó árbevétel/állományi létszám & Eredménykimutatás/beszámoló \\
\hline
\end{tabular}

Forrás: saját szerkesztés

\section{OUTPUTINDIKÁTOROK}

A közösségi (nem pénzügyi) vállalatok output oldalának vizsgálatába négy indikátort (megújulási képesség, értékteremtés, vagyongyarapodás/gazdálkodás, környezeti terhelés) vontunk be.

\section{Megújulási képesség részindexe}

A megújulás a vállalati fenntarthatóság kiemelt jelentőségű eleme, nem véletlen, hogy a szakirodalom kiemelten kezeli a vállalati megújulási képességet (OECD, 2013a; OECD, 2013b). A megújulási képesség több tényező (technológia, kompetencia, termék/szolgáltatás portfólió, hozzáadott érték, minőség, gazdálkodás, kereslet) függvénye.

A megújulási képesség hiánya piacvesztéshez, az értékteremtő képesség csökkenéséhez, beruházások átütemezéséhez, elmaradásához, a környezeti terhelés növekedéséhez, vagyonvesztéshez, hitelképesség csökkenéséhez vezet, amelynek végeredménye csőd és a felszámolási eljárás megindítása lehet (11. ábra). ${ }^{19}$

\section{Technikai, technológiai megújulás mutatója}

Technikai, technológiai megújulás minden olyan tudatos változtatás, ami a meglévő eszközök, berendezések, rendszerek, technikák, eljárások korszerűsítésére, termelékenységének javítására, hatásfokának növelésére, kockázati tényezőinek csökkentésére irányul.

A fogalom könnyen értelmezhető, ma már a hazai szakirodalom (nem utolsósorban az EUpályázatoknak, pl. TÁMOP stb. köszönhetően) gyakori témája a technikai, technológiai megújulás, ennek ellenére mégis ritkán (többnyire csak pályázati indikátorokként) számszerüsítik. ${ }^{20}$

A rendszeres technikai, technológiai megújulási képesség fenntartása ráfordítás(beruházás-) igényes, ezért mérésekor ennek költségeivel kell számolni (8. táblázat).

Az aggregált mutató a két részmutató számtani átlaga. A mutató értékét torzíthatja:

- az amortizáció elszámolásának módja, ${ }^{21}$

- a saját fejlesztések értékének meghatározása, illetve aktiválása.

\section{Termék, szolgáltatási portfólió megújulásának mutatója}

A termék és szolgáltatási tevékenység megújulása minden olyan tudatos, a vállalat stratégiájával összhangban lévő változás (változtatás), amely a fogyasztók (felhasználók) jobb, hatékonyabb elérhetőségét, kiszolgálását, a szolgáltatások bővülését biztosítja.

A vállalatokat a $\mathrm{KSH}$ évente termékstatisztikai jelentésre kötelezi, amit a KSH 1039. számú nyomtatvány felhasználásával kell megtenniük. Ennek összeállításához szükség van az érintett termékek/szolgáltatások megnevezésé- 


\section{MEGÚJULÁSI KÉPESSÉG CSÖKKENTÉSÉNEK POTENCIÁLIS HATÁSA}

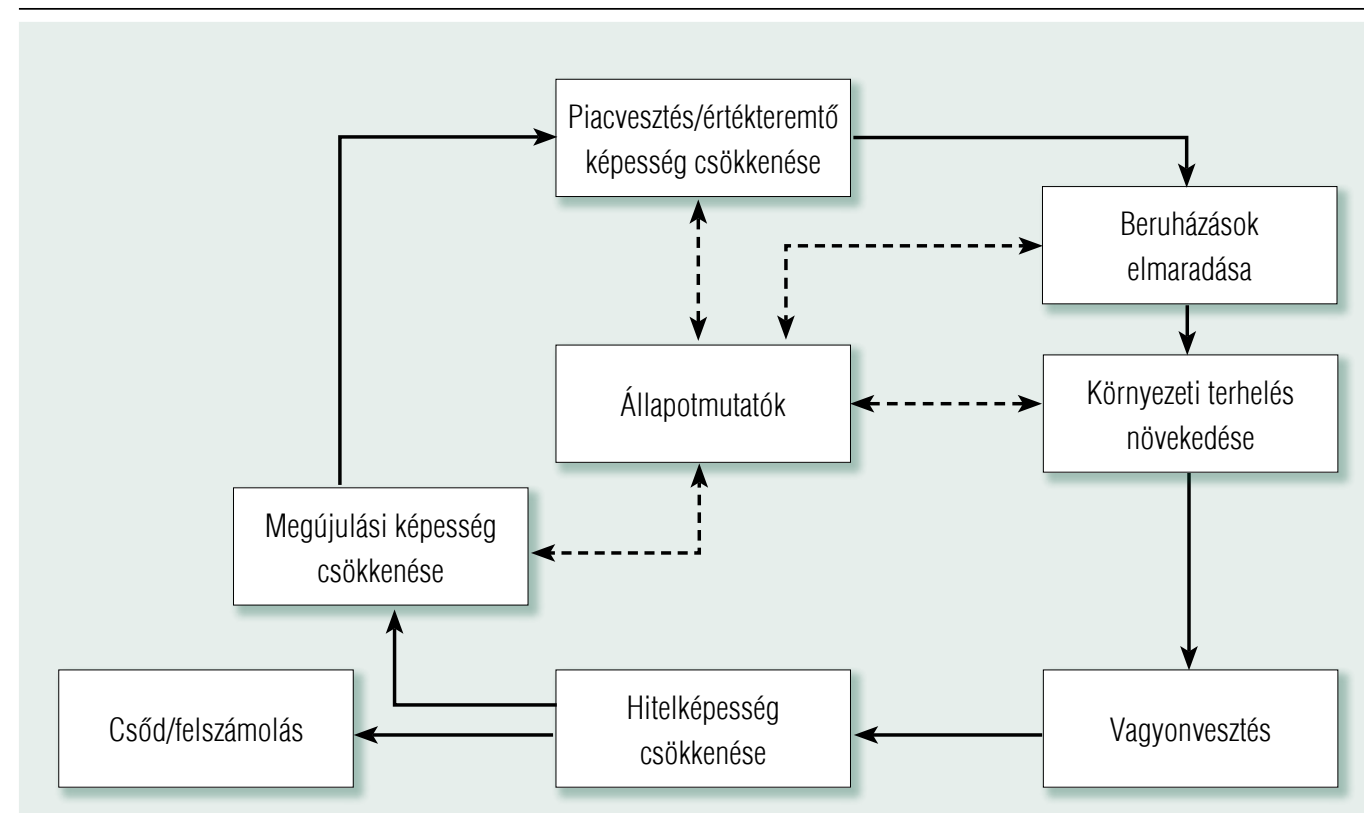

Forrás: saját szerkesztés

8. táblázat

\section{TECHNIKAI, TECHNOLÓGIAI MEGÚJULÁS MÉRÉSE}

\begin{tabular}{c|l|l|l|}
\hline \multicolumn{1}{|c|}{ Ssz. } & \multicolumn{1}{|c|}{ Megnevezós } & \multicolumn{1}{c}{ Számszertísítés } & \multicolumn{1}{c}{ Adatok forrása } \\
\hline 1. & $\begin{array}{l}\text { Technológiai megújulási } \\
\text { képesség }\end{array}$ & $\begin{array}{l}\text { (vásárolt + saját fejlesztésū technológia } \\
\text { költsége)/ éves nettó árbevétel }\end{array}$ & Eredménymutatók \\
\hline 2. & Eszközmegújulási képesség & Éves beruházási ktsg./ nettó tőkeállomány & Eredménykimutatás \\
\hline
\end{tabular}

Forrás: saját szerkesztés

re, kódszámára (az éves termékjegyzék szerint), az értékesített mennyiségre és az abból származó nettó árbevételre.

Ebből a kimutatásból (figyelembe véve az előző év hasonló adatait) kiolvasható az új termék/ szolgáltatás nagysága (lehetnek olyan ágazatok, ahol ezen túlmenően is lehetnek a szolgáltatások körének változására vonatkozóan adatok).

A vizsgált hőszolgáltatás esetében a szolgáltatási portfólió változása további két mutató segítségével mérhető (9. táblázat).
A termék/szolgáltatási portfólió megújulási mutató a két részmutató számtani átlaga alapján határozható meg. ${ }^{22}$

\section{Szervezeti, irányitási megújulás mutatója}

A szervezeti, irányítási megújulás minden olyan tudatosan végrehajtott változás (változtatás), ami a vállalat víziójával, stratégiával összhangban, működésének költségérzékenységét, átláthatóságát, teljesítményét, integritását javítja. 
9. táblázat

\section{SZOLGÁLTATÁSI PORTFÓLIÓ MEGÚJULÁSÁNAK MUTATÓI EGY HŐSZOLGÁLTATÓ VÁLLALAT ESETÉBEN}

\begin{tabular}{c|l|l|l|}
\hline Ssz. & \multicolumn{1}{|c}{ Megnevezés } & \multicolumn{1}{c}{ Számszerísítés } & \multicolumn{1}{c}{ Adott forrás } \\
\hline 1. & Hálózatsúrúség változása & $\begin{array}{l}\text { [új hálózat hossza (km, év)/ régi hálózat } \\
\text { hossza] }\end{array}$ & Beruházási adatok \\
\hline 2. Értékesitési árbevétel változása & $\begin{array}{l}\text { [új belépőtől származó árbevétel (eFt/ } \\
\text { háztatás, év) / régi fogyasztók árbevétele] }\end{array}$ & $\begin{array}{l}\text { Vállalati árbevétel/ } \\
\text { költségkimutatás }\end{array}$
\end{tabular}

Forrás: saját szerkesztés

10. táblázat

\section{A SZERVEZETI, IRÁNYÍTÁSI MEGÚJULÁS MUTATÓI}

\begin{tabular}{|c|c|c|c|}
\hline ssz. & Megnevezés & Számszertísítés & Adatok forrása \\
\hline 1. & IT-színvonalráta & $\begin{array}{l}\text { [(éves nettó IT beruházási + üzemeltetési } \\
\text { ktsg)/éves nettó eredmény] }\end{array}$ & Főkönyv \\
\hline 2. & Folyamat/szervezetátalakítási ráta & $\begin{array}{l}\text { (éves nettó folyamatszervezési költség/ } \\
\text { éves nettó eredmény) }\end{array}$ & Főkönyv \\
\hline
\end{tabular}

Forrás: saját szerkesztés

Az előbbi definíciónak megfelelően a szervezeti megújulás része lehet az információs és a döntési rendszer, a stratégiaalkotás folyamatának és kidolgozásának, a szervezeti egységek feladat, hatás és felelősségi körének, a hierarchikus szintek számának változtatása, hatékonyságának növelése. ${ }^{23}$

A szervezet, illetve irányítási rendszer megújításának célja a működés eredményességének, hatékonyságának növelése, a munkahelyi klíma javítása, amelynek jelentkeznie kell a vállalati eredményben is. A mutatók fökönyvi adatok felhasználásával határozhatók meg (10. táblázat).

A vállalatirányítási rendszer megújulását (a nemzetközi szakirodalommal összhangban) pl. az integrált, számítógéppel támogatott vállalati erőforrás-tervezési rendszer (ERP-Enterprise Resource Planning) bevezetése, működtetése je- lenti. (A mutatók a fókönyvi adatok alapján könnyen, viszonylag kockázatmentesen határozhatók meg.)

\section{Értékteremtési részindex}

A vállalat által eloállított érték adott termék/ szolgáltatás hasznosságát, minőségét fejezi ki, ami nagyobb haszonhoz, eredményhez, sikerhez vezet. ${ }^{24}$

A vállalat által előállított érték, illetve a vállalati érték nem szinonim fogalmak.

A modellünkben tudatosan a vállalat által elóállított érték, nem pedig a vállalati érték szerepel. Ez utóbbi függ a piaci értéken számított eszközarányos nyereségtől (MROA), tőzsdevállalat esetében a részvények árfolyamától stb. ${ }^{25}$ 


\section{Minöség/megbizhatóság biztositásának mutatója}

A minőség kifejezi, hogy a valós igényt kielégítő termék/szolgáltatás milyen mértékben és formában (megbízhatóság, szabványnak való megfelelés, rendeltetés szerinti hasznosság) elégíti ki adott fogyasztói/felhasználói kör igényét (ISO 8402).

A minőség gazdaságtanának, illetve a minőségnek a vállalati eredményességre, versenyképességre vonatkozó szakirodalma gazdag (pl. Anderson et al., 1994; Herman és Johnson, 1999, stb.), az ezzel kapcsolatos ismeretek mind a műszaki, mind a közgazdasági felsőoktatás részét képezik. Az adatok ismeretében a minőségbiztosítás érdekében eszközölt éves nettó árbevétel arányos ráfordítások mértéke határozható meg (11. táblázat). ${ }^{26}$

A mutatók értékszemléletűek, a fogyasztói igényt kívánják összhangba hozni az árral.

A minőségfenntarthatósági index a fenti két mutató átlagolásával határozható meg az alábbiak szerint: [(éves nettó minőségbiztosítási költség + éves nettó panaszelhárítási költség) / éves nettó árbevétel] $\times 100$.

Minőségcontrollingot alkalmazó vállalkozások a két, esetenként ellentétes hatású költségráfordítást tudatosan tudják befolyásolni, illetve optimalizálni.

Az értékelés során figyelembe kell venni:

- az ágazati specifikumokat (pl. előállított termékek/szolgáltatások típusa, összetétele stb.),

- a minőségbiztosítási szervezet nagyságát (pl. működési költségeit stb.).

A mutató meghatározásakor jelentkező kockázatok: pontatlan költséghelyi, költségviselői lehatárolások, hibaelhárítás, a kiküszöbölés költségeinek pontatlan elszámolása.

\section{Hozzáadott érték mutatója}

Termék/szolgáltatás hozzáadott értéke: az időszak alatti árbevétel és a vásárolt áruk, szolgáltatások értékének különbsége. Érdemes megjegyezni, hogy a tőzsdére bevezetett részvénytársaságoknál - ahol a menedzsmenttel szemben elvárás, hogy növeljék a vállalat részvényárfolyamát - számszerüsítik az úgynevezett piaci hozzáadott értéket (MVA) és a gazdasági hozzáadott értéket (EVA) is.

A hozzáadott érték előjele és nagysága a fenntartható gazdálkodás fontos értékmérōje (negatív érték gyakorlatilag értékcsökkenést jelent), mert a lekötött tőke megtérülése (ROCE) csökken. ${ }^{27}$

A szakirodalom a hozzáadott érték megszerzésére és számítására többfajta módszert is ismer (12. táblázat).

A mutatók meghatározásakor torzító lehet: az amortizáció elszámolásának módja, a készletnyilvántartások pontossága, időbeli elhatárolások, a kis értékű vásárolt eszközök elszámolásának módja.

11. táblázat

\section{A MINŐSÉG FENNTARTHATÓSÁGÁNAK MUTATÓI}

\begin{tabular}{|l|l|l|l}
\hline Ssz. & \multicolumn{1}{|c|}{ Megnevezés } & \multicolumn{1}{c}{ Mérés } & \multicolumn{1}{c}{ Adatok forrása } \\
\hline 1. & Minőségbiztosítási ráta & $\begin{array}{l}\text { (éves nettó minőségbiztosítási ktsg/ éves } \\
\text { nettó árbevétel) }\end{array}$ & Főkönyv \\
\hline 2. & Panaszelhárítás mutatója & $\begin{array}{l}\text { (éves nettó panaszelháritási ktsg/ éves } \\
\text { nettó árbevétel) }\end{array}$ & \\
\hline
\end{tabular}

Forrás: saját szerkesztés 


\section{BRUTTÓ ÉS NETTÓ HOZZÁADOTT ÉRTÉK MUTATÓI}

\begin{tabular}{|c|c|c|c|}
\hline Ssz. & Megnevezés & Meghatározás & Adatok forrása \\
\hline 1. & Bruttó hozzáadott érték mutatója & $\begin{array}{l}\text { [nettó árbevétel / (nettó árbevétel } \\
\text { + saját előállitású eszközök aktivált } \\
\text { értéke - eladott áruk beszerzési értéke } \\
\text { (ELÁBÉ) - közvetített szolgáltatások } \\
\text { + saját termelésú készletek } \\
\text { állományváltozása - anyag és energia } \\
\text { költség - igénybe vett szolgáltatások } \\
\text { - egyéb szolgáltatás + termék és } \\
\text { termelési támogatások - termék és } \\
\text { termelési adók)] }\end{array}$ & \multirow[t]{2}{*}{$\begin{array}{l}\text { Mérleg, } \\
\text { szöveges beszámoló }\end{array}$} \\
\hline 2. & Nettó hozzáadott érték mutatója & $\begin{array}{l}\text { [nettó árbevétel / (nettó árbevétel } \\
\text { + saját előállitású eszközök aktivált } \\
\text { értéke - eladott áruk beszerzési értéke } \\
\text { (ELÁBÉ) - közvetített szolgáltatások - } \\
\text { amortizáció + saját termelésú készletek } \\
\text { állományváltozása - anyag és energia } \\
\text { költség - igénybe vett szolgáltatások } \\
\text { - egyéb szolgáltatás + termék és } \\
\text { termelési támogatások - termék és } \\
\text { termelési adók)] }\end{array}$ & \\
\hline
\end{tabular}

Forrás: saját szerkesztés

Vagyongyarapodási, gazdálkodási index

A vagyon a vállalkozás múködtetéséhez szükséges anyagi és nem anyagi javak összessége. Az eszközök (aktívák) a vagyonnak a termelésben/szolgáltatásban betöltött (befektetett eszközök, forgóeszközök, aktív időbeli elhatárolások) szerepét (megjelenési formáit), a források (passzívák) a vállalkozói vagyon eredetét, finanszírozási forrásait (saját tőke, céltartalékok, kötelezettségek, passzív időbeli elhatárolások) fejezik ki.

A vagyonvesztés a vállalat súlyos működési, gazdálkodási, likviditási zavaraira utal (12. ábra).

\section{Vagyoni helyzet, tökehatékonyság}

A vagyongyarapodással, gazdálkodással kapcsolatos fogalmak közismertek, az érintett szakterület az éves mérleg, eredménykimutatás készítésekor rendszeresen számszerűsíti, a beszámolókban szövegesen is értékeli. Ezért ezeknek a mutatóknak a meghatározása nem jelent többletfeladatot.

A vagyon alapvető célja a közfeladat ellátásának biztosítása, a közérdek szolgálata, a közös szükségletek kielégítése. ${ }^{28}$

A vagyongazdálkodás a rendelkezésre álló, egymással valamilyen módon a kapcsolatban és kölcsönhatásban álló eszközök eredőjeként megjelenő vagyon megőrzésére gyarapítására és hasznosítására irányul. ${ }^{29} \mathrm{~A}$ vagyonmeg- 


\section{A VAGYONVESZTÉS TOVAGYỨRŨZZ̃ HATÁSAI}

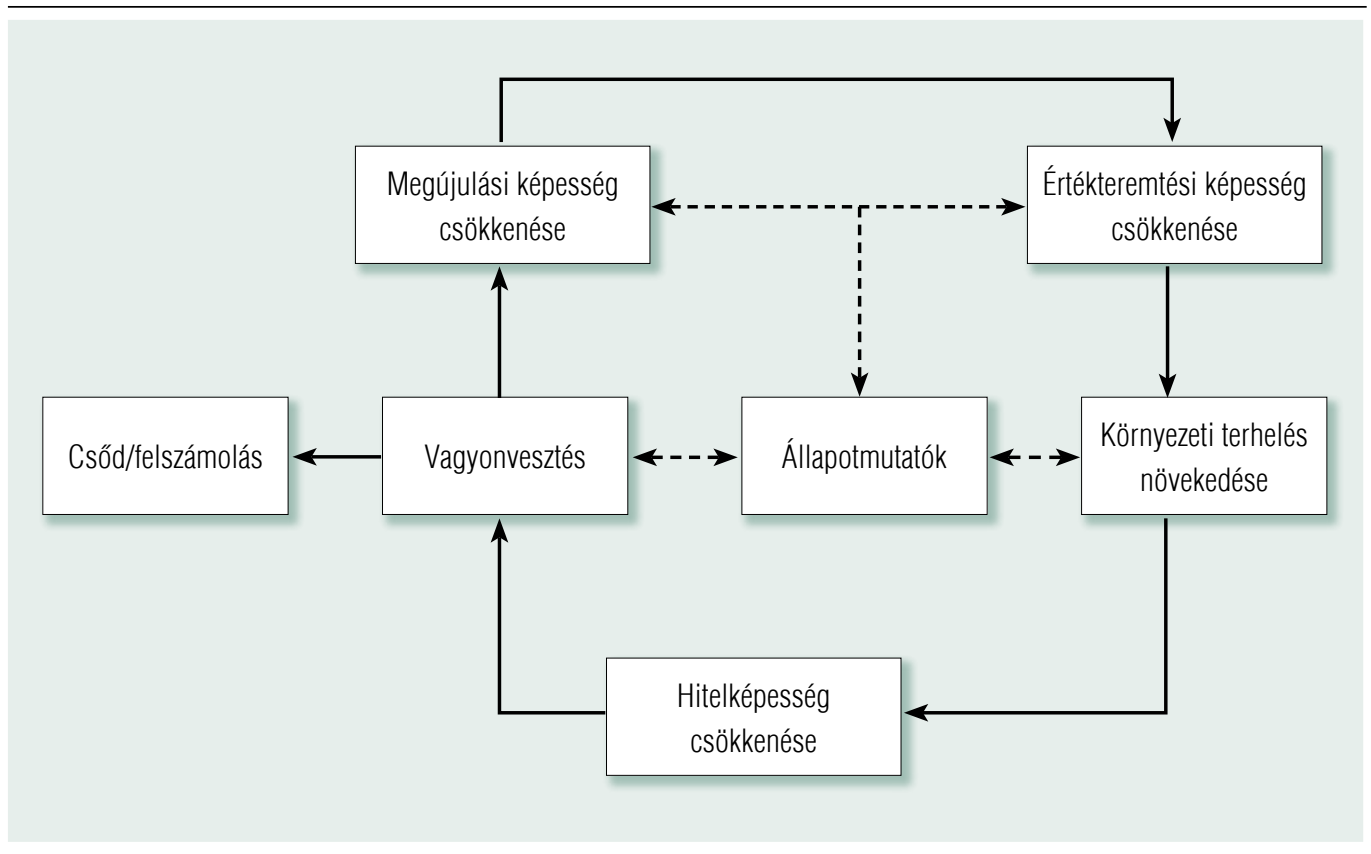

Forrás: saját szerkesztés

őrzés alapvetően a „jó gazda” gondosságával járó kezelést; a vagyongyarapítás a bevételeknek a befektetés/beruházás irányába való terelését, míg a vagyonhasznosítás a bérbe adástól a hasznosításig terjedő tevékenységeket foglalja magába.

Az index a vállalati vagyon változásának dinamikáját fejezi ki.

A vagyoni helyzet, illetve a tőkehatékonyság az adott vállalkozás helyzetének, működése fenntarthatóságának fontos módszere.

A vállalkozás mérlege alapján több eszköz- és tőkeszerkezeti mutató képezhető (13. táblázat).

A modell szempontjából elsősorban azok a mutatók relevánsak, amelyek százalékos formában fejezik ki a vállalkozás vagyoni helyzetét, illetve annak év/év típusú változását.

A vagyoni helyzet és a tőkehatékonyság változását kifejező mutatók meghatározásának kockázata viszonylag alacsony, ami annak köszönhető, hogy a mutatókat az eredménykimutatás és mérleg adatai alapján kell meghatározni. A kockázatok tehát ezeknek az adatoknak a manipulálásából adódhatnak (pl. amortizáció elhatárolás, időbeli elhatárolások stb.).

\section{Jövedelmezöség, likviditási helyzet}

A jövedelmezőség azt fejezi ki, hogy a vállalat milyen eredménnyel használja fel a rendelkezésére bocsátott erőforrásokat (munkaerő, technológia, tőke).

A mutatóval kapcsolatos fogalmak, ismeretek az éves beszámolóhoz kapcsolódó szöveges értékelésekben szerepelnek, így meghatározásuk nem jelent többletfeladatot.

A jövedelmezőség a vállalat adott időszaki (éves tevékenységének) eredményét vizsgálja különböző (az eredménykimutatásból, illetve a mérlegből nyert) mutatószámok segítségével.

A jövedelmezőség elemzése viszonyszámok (eredménykategória/vetítési alap) alapján történik. 


\section{VÁLLALKOZÁS TŐKEERŐSSÉGÉT, TŐKESZERKEZETÉT KIFEJEZŐ MUTATÓK}

\begin{tabular}{|c|c|c|c|}
\hline Ssz. & Megnevezés & Számítási mód & Adatok forrása \\
\hline 1. & Tőkeerősség & (saját tőke/összes forrás) & \multirow[t]{7}{*}{ Mérleg, szöveges beszámoló } \\
\hline 2. & Saját tőke növekedési mutató & (saját tôke/jegyzett tőke) & \\
\hline 3. & Befektetett eszközök fedezettsége & (saját tőke/befektetett eszközök) & \\
\hline 4. & Eszközök fordulatszáma & (nettó árbevétel/összes eszköz) & \\
\hline 5. & Tőke hatékonysága & (adózott eredmény/saját tőke) & \\
\hline 6. & Befektetett eszközök aránya & (befektetett eszköz/összes eszköz) & \\
\hline 7. & Saját tőke fordulatszáma & (nettó árbevétel/saját tôke) & \\
\hline
\end{tabular}

Forrás: saját szerkesztés

A vállalat jövedelmezőségére vonatkozó számításokat a számviteli törvény által elöírt beszámoló kiegészítő melléklete tartalmazza (a leggyakrabban használt mutatókat a 14. táblázat foglalja össze).

\section{Környezeti fenntarthatósági részindex}

A neoklasszikus közgazdaságtan felfogása szerint a környezeti terhelés ${ }^{30}$ csökkentése növeli a vállalatköltségeket, csökkenti a versenyképességet (ne- gatív externália). Ezzel szemben Porter a vállalatok környezeti terhelését hatékonytalanságként, pazarlásként (pl. anyag, energia stb.) fogja fel (Porter, Linde, 1995).

Porter az innovációorientált vállalati magatartásban (pl. új anyagok és technológiák bevezetésével) látja a környezeti terheléssel járó költségek csökkentésének a vállalati versenyképesség megtartásának lehetőségét. ${ }^{31}$

A két irányzat közötti különbség megítélése nyilván összetettebb, gazdasági célokon túl társadalmi felelősség (ökológiai, egészsé-

14. táblázat

\section{A JÖVEDELMEZŐSÉG VIZSGÁLATÁNAK MUTATÓI}

\begin{tabular}{|l|l|l|l|}
\hline Ssz. & \multicolumn{1}{|c|}{ Megnevezés } & \multicolumn{1}{c|}{ Számítási mód } & \multicolumn{1}{c}{ Adatok forrása } \\
\hline 1. & Eszközhatékonyság - ROI & (adózott eredmény/összes eszköz) & Eredménykimutatás \\
\hline 2. & Tőkearányos eredmény - RDE & (adózott eredmény/saját tôke) & \\
\hline 3. & $\begin{array}{l}\text { Árbevétel-arányos üzleti } \\
\text { eredmény }\end{array}$ & (üzleti eredmény/nettó árbevétel) \\
\hline 4. & Cashflow-rés & (szűkített cashflow/nettó árbevétel) \\
\hline 5. & $\begin{array}{l}\text { Eredményarányos eszközlekötés } \\
\text { - ROA }\end{array}$ & (adózás előtti eredmény/összes eszköz) \\
\hline
\end{tabular}

Forrás: saját szerkesztés 
gi) vállalását várja el a vállalati menedzsmentektől.

A vállalati fenntarthatóság ugyanis nem egyetlen tényezőt (az éves adózott eredményt) kíván rövid távon maximalizálni, hanem a müködés fenntarthatóságát. ${ }^{32}$

Környezetközpontú irányítási rendszert (KIR), ${ }^{33}$ illetve az ISO 14001-es szabványt alkalmazó vállalatok ismerték a környezeti terheléssel, szennyezéssel kapcsolatos fogalmakat, és számszerüsítésének módját (a környezeti kockázatok becslésére vonatkozó irányelvek előírják a levegő, a föld és a víz esetében jelentkező kockázatok nagyságát). Ennek alapján a gazdálkodó szervezetek évente kötelesek a környezetterhelési díjelőleget, illetve az éves díjkötelezettségüket bevallani (NAV-1850 számú bevallás). A hazai vállalatok többsége esetében azonban ez még alapvetően új.

A vállalat környezeti terhelésének csökkentése érdekében három mutatót számszerűsít a modell (15. táblázat).

A környezeti terhelés változása a három mutató egyszerủ számtani átlagának változása alapján mérhető. (A vizsgált vállalatnál számszerüsítik a fenti adatokat, de azokat üzleti titokként kezelik, így azokat nem bocsátották rendelkezésünkre.)

A mutatóval kapcsolatos számítások esetében kockázatot jelenthet:

- a „kozmetikázott” adatok, amelyekkel a vállalatok a környezeti terheléssel járó dí- jak, (2003. évi LXXXIX. törvény környezetterhelési díjról), illetve büntetések megfizetését kívánják elkerülni,

- az eredmény nem független az ágazattól (pl. alapdíj/hődíj/használati melegvízdíj díjszámítási módjától).

\section{EMPIRIKUS TAPASZTALATOK}

Modellünk alkalmazhatóságát egy vízközmű vállalat 2010-2017 közötti publikus adatainak felhasználásával teszteltük.

Első lépésben az adatok hozzáférhetőségén túl az egyes mutatók illetve részindexek közötti kapcsolatok szorosságát vizsgáltuk (a számítások során a környezeti részindexet figyelmen kívül hagytuk tekintettel arra, hogy visszamenő adatok nem álltak rendelkezésre, az integritási részindex vonatkozásában pedig csak az etikai megfelelésre vonatkozóan rendelkeztünk adatokkal).

Az hatszor hatos korrelációs mátrix adatainak többsége közepes erősségű kapcsolatot tárt fel a részindexek között (13. ábra).

Második lépésben határoztuk meg a kompozit indexet.

A hat eltérő jellegű részindex alapján standardizálás módszerét változtattuk, ami százalékos formában fejezi ki a vállalati fenntarthatóság időbeli változását (0 és 100 között). Ennek érdekében az egyes részindexek eseté-

15. táblázat

\section{KÖRNYEZETI TERHELÉS CSÖKKENTÉSÉNEK MUTATÓI}

\begin{tabular}{c|l|l|l} 
Ssz. & \multicolumn{2}{|c|}{ Megnevezés } & \multicolumn{1}{c}{$\begin{array}{c}\text { Számítási mód } \\
\text { Adatok } \\
\text { forrása }\end{array}$} \\
\hline 1. & Levegőterhelési díj aránya & (levegőterhelési díj/nettó árbevétel) & Főkönyv, műszaki adatok \\
\hline 2. & Vízterhelési díj aránya & (vízterhelési díj/nettó árbevétel) & \\
\hline 3. & Talajterhelési díj arány & (talajterhelési díj/nettó árbevétel) & \\
\hline
\end{tabular}




\section{TESZTVIZSGÁLAT KORRELÁCIÓS MÁTRIXA}

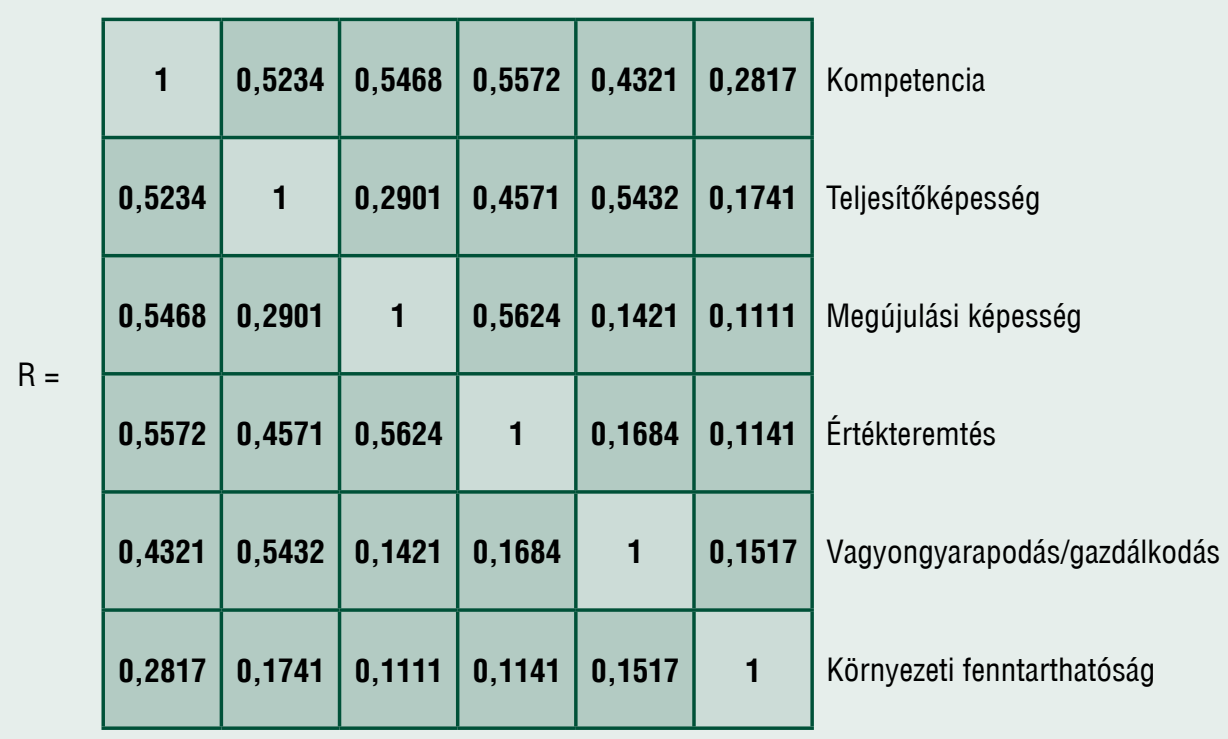

Forrás: saját szerkesztés

16. táblázat

\section{RÉSZINDEX MUTATÓINAK NAGYSÁGA (2010-2017)}

\begin{tabular}{|c|c|c|c|c|}
\hline Ssz. & Részindex & Mutató & Min. & Max. \\
\hline \multirow[t]{2}{*}{1.} & \multirow[t]{2}{*}{ Integritási részindex } & Jogszabályi megfelelés & 0,210 & 0,720 \\
\hline & & Etikai megfelelés & 0,340 & 0,820 \\
\hline \multirow[t]{2}{*}{2.} & \multirow[t]{2}{*}{ Kompetencia részindex } & Egyéni kompetencia & 0,410 & 0,810 \\
\hline & & Szervezeti kompetencia & 0,380 & 0,790 \\
\hline \multirow[t]{2}{*}{3.} & \multirow[t]{2}{*}{ Teljesítőképesség részindex } & Átbocsátó képesség & 102481,000 & 123111,000 \\
\hline & & Termelékenység & 3810000,000 & 4022000,000 \\
\hline \multirow[t]{3}{*}{4.} & \multirow[t]{3}{*}{ Megújulási képesség részindexe } & Technikai/technológiai megújulás & 0,00001 & 0,00001 \\
\hline & & Porttólió megújulás & 0,000013 & 0,000021 \\
\hline & & Szervezeti/irányítási megújulás & 0,000001 & 0,00000101 \\
\hline \multirow[t]{2}{*}{5.} & \multirow[t]{2}{*}{ Értékteremtési részindex } & ROA & $-2,000$ & 3,60 \\
\hline & & ROI & - & - \\
\hline \multirow[t]{3}{*}{6.} & \multirow[t]{3}{*}{ Vagyoni helyzet részindex } & Tőkeerősség & 17,600 & 24,200 \\
\hline & & ROI & $-1,100$ & 10,300 \\
\hline & & Befektetett eszköz & 0,991 & 1,078 \\
\hline
\end{tabular}

Forrás: saját szerkesztés 
ben meghatároztuk a minimális és maximális értékeket (16. táblázat) és ehhez kalibrálható a vizsgálati érték, ami a vizsgált időszakban (2010-2017) 37 és 43 százalék között változhat.

A másik kérdés, amire választ kerestünk: hogyan befolyásolják a részindexek a fenntarthatósági index értékét?

A dekompozíció azt igazolta, hogy az adott vállalat esetében a megújulási és az értékteremtési részindex jelenti a gyenge pontot (14. ábra).

\section{ÖSSZEFOGLALÁS}

Egyetlen, az össztársadalmi értékek iránt elkötelezett gazdaságpolitika sem nélkülözheti a duális tulajdonosi formát. A dualitás azonban nem jelent szerkezeti állandóságot, az állami és a magántulajdon aránya időben és térben egyaránt változhat, másrészt az állam reál gazdasági szerepvállalása nem járhat a közösségi tulajdon keretei között müködő társaságok termelékenységének romlásával, költségérzéketlenségével és versenyhátrányával.

$\mathrm{Az}$ állami vagyon nagyságrendje, gazdasági és társadalmi jelentősége az állami tulajdonú vállalatok fenntarthatóságának folyamatos monitorizálását, és szükség esetén a kívánt beavatkozások kidolgozását teszi indokolttá.

A hat részindexből (megújulási képesség, értékteremtés, integritás, kompetencia, vagyongyarapodás, környezet) álló kompozitmutató alkalmazásával lehetőség van a fenntarthatóságon túl egyrészt az ágazaton belüli, másrészt az ágazatok közötti összehasonlításra és ennek alapján a tulajdonosi beavatkozásra.

\section{FENNTARTHATÓSÁG DEKOMPOZÍCIÓJA}

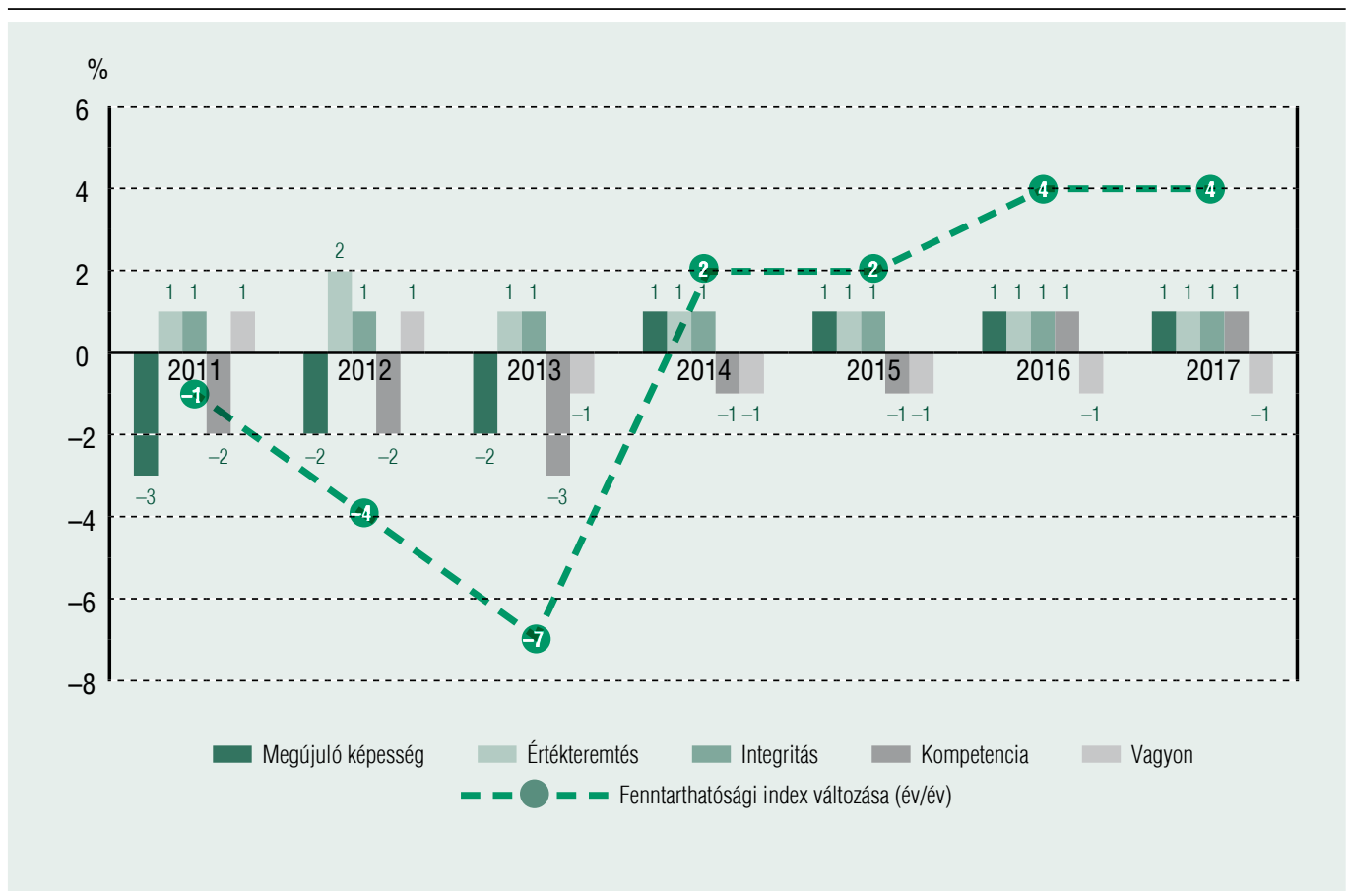

Forrás: saját szerkesztés 
A fenntartható vállalati fejlődés eszközrendszere (értékmenedzsment, környezetmenedzsment, változásmenedzsment, vagyonmenedzsment, tudásmenedzsment, motivációs menedzsment) adott. Elsősorban a felső vezetés felkészültségétől, elkötelezettségétől függ, hogy ezeket az eszközöket mire, hogyan és milyen eredménnyel tudja alkalmazni.

\section{JEGYZETEK}

1 Az új elméletek kiemelten foglalkoznak az államnak a technológiai fejlődésben betöltött szerepével, a stratégiai iparágak védelmével és fejlesztésével, a nemzetközi munkamegosztásra gyakorolt hatásával, az állami tulajdonú gazdasági társaságok ellenőrzési (Milicz, 2016), az állami és önkormányzati tulajdonú gazdasági társaságok irányítási kérdéseivel (Domokos et al., 2016).

2 Fordulat következett be a fejlett nyugat-európai országok államtulajdonosi gyakorlatában a 20 . században. A Milton Friedman és August von Hayek nevével fémjelzett neoliberális gazdaságpolitika időszakában általánossá vált az a felfogás, hogy az állam rossz tulajdonos, ezért a tulajdonában lévő vállalatok gyengébb piaci szereplők az azonos profilú magántőke-társaságoknál. A 2008-as pénzügyi válságot követően e téren is paradigmaváltás következett be, nőtt az állami szerepvállalás mértéke (Dietrich, 2012). Hazánkban az 1989 után végbement geopolitikai, ideológiai változások hatására (több mint 40 év után) vált ismét lehetővé a duális (állami és magán) tulajdoni forma kiépítése, a tulajdoni arányok megváltoztatása, az állami tulajdon magánkézbe adása, ami különösen a kezdeti időszakban komoly gondot okozott egyrészt a jogszabályi háttér, másrészt a privatizáció módszertanának kiforratlansága miatt. A 2010 után bekövetkezett gazdaságpolitikai fordulat hatására hazánkban is átértékelődött az állami tulajdon szerepe.

3 A nemzeti számlák korábbi módszertani kézikönyvei (SNA 93, ESA 95) ajánlásként tartalmazták a pénzügyi (S.12) és a nem pénzügyi (S.11) vállalati szektor bontását fötulajdonos-szektorok szerint. A megújított kézikönyvek (SNA 2008, ESA 2010) ezen belül kiemelten foglalkoznak a közösségi vállalatok körével: egyrészt definiálják a közösségi szektor fogalmát, amely az államháztartás és a közösségi vállalatok együttese, másrészt számos ponton szabályozzák a tulajdonosok (kormányzati szervek) és a tulajdonukban lévő vállalatok közötti pénzügyi kapcsolatok statisztikai elszámolását.

4 A 2013-2017 közötti újraállamosítás szerény pozitív hatással volt a társaságok főbb gazdasági mutatóira, miközben a kormányzat ellenőrzési, irányítási feladatai megnőttek.

5 A szakirodalom szerint az ökológiai fenntarthatóság fogalmát az erdőhasználat kapcsán alkalmazta először a német származású Carlowitz a 18. században (olyan mértékủ lehet csak a faállomány kitermelése, ami nem veszélyezteti az erdő reprodukciós képességét, idézi: Somogyi, 2015. p. 10).

${ }^{6}$ Schallhart (2011) a következő vállalattípusokat különbözteti meg:

- impulzív vállalat, amelynek stratégiai célja az agresszív piacszervezés és a siker,

- lojális vállalat, amely a hierarchikus felépítésű, tradicionális értékekre és a hatékonyságra helyezi a hangsúlyt,

- stratégiai vállalat, amely a nyereség maximalizálására és a versenytársakra helyezi a hangsúlyt,

- megújuló vállalat, amely a közösségi érdeket kívánja fenntartható módon szolgálni. 
7 Megítélésünk szerint az eloállított termék/szolgáltatás ára nem alkalmas az ökológiai fenntarthatóság biztosítására.

8 A vállalati fenntarthatósággal kapcsolatos szakirodalom különbséget tesz a teljesítmény és környezeti szempontú fenntarthatóság között (Aier, Dogan 2005). A makrogazdaságtan által alkalmazott fenntartható fejlődés fogalma ettől eltér. A Brundtlandjelentés szerint „a fejlödés olyan formája, amely a jelen igényeinek kielégitése mellett nem fosztja meg a jövö generációját saját szükségletének lehetöségeitöl" (Meadows et al., 1972).

9 A számviteli törvény is kiemeli a vállalkozás folytatásának elvét, amely szerint „a beszámoló elkészitésekor és a könyvvezetés során abból kell kiindulni, hogy a gazdálkodó a belátható jövöben is fenn tudja tartani müködését, folytatni tudja tevékenységét, nem várható a müködés beszüntetése vagy bármilyen okból történö jelentös csökkenése" [2000. évi c. törvény a számvitelről 15. (1)].

${ }^{10}$ A hazai közösségi tulajdonú vállalatok komplex, fenntarthatósági szemléletű vizsgálatára - ismereteink szerint - ez az első kísérlet. A nemzetközi szakirodalomban vannak ugyan erre vonatkozó ajánlások, de a részletes elemzések (vélelmezhetően vállalatgazdaságtani és stratégiai stb. megfontolásokból) nem hozzáférhetők.

${ }^{11} \mathrm{Az}$ indikátorok száma természetesen tovább bővíthető. Meghatározásukkor arra törekedtünk, hogy egyrészt általánosíthatók, több ágazat esetében is alkalmazhatók, másrészt reális időn belül számszerüsíthetők legyenek.

${ }^{12}$ Az ellenőrzés alá vont vállalatok önkéntes alapon, az Állami Számvevőszék honlapján rendelkezésre álló kérdőívet letöltve értékelik (értékelhetik) ma is tevékenységüket (ez a technikai támogatás megkönnyíti a kérdőív kitöltését).

${ }^{13}$ A kompetencia és a vállalati teljesítmény közötti összefüggések kauzális vizsgálatának és empirikus elemzésének kiterjedt szakirodalma van (lásd pl. Boyatzis, 1981; Büser, 2004).

${ }^{14}$ A kompetencia igényoldalához való alkalmazkodásban egyre nagyobb szerepe van a szakképzésnek és a felsőoktatásnak. Ezt segítették többek között a TÁMOP-projektek is.

15 „A kompetenciát úgy kell tekinteni, mint olyan általános képességet, amely a tudáson, a tapasztalaton, az értékeken és a diszpoziciókon alapszik, amit egy adott személy tanulás során fejleszt ki." (EC, 2002. p. 5)

${ }^{16}$ A tudás szerepének vállalati jelentőségével kapcsolatos szakirodalom részletesebb elemzése megtalálható, Bélyácz, Kovács, 2017.

${ }^{17}$ Érdemes az előzmények kapcsán megjegyezni, hogy a közigazgatásra vonatkozó kompetenciaalapú szervezeti struktúra kialakításának lehetőségeit tárgyalja többek között Báger, Balogh, 2010; Wildemann. 2009; Veresné, 2005 munkája.

${ }^{18}$ A teljesítőképesség, illetve a termelékenység mint azt az empirikus elemzések igazolják (lásd pl. EANPC, 2013) - korrelációs kapcsolatban áll a termelési (kibocsátási) volumennel, árbevétellel, a hozzáadott értékkel és az eredménnyel.

${ }^{19}$ A szakirodalom a megújulási képesség vizsgálatát elsősorban a vállalati beruházásokhoz, illetve a $\mathrm{K}+\mathrm{F}+\mathrm{I}$-ráfordításokhoz köti, mint azt Belitz et al. (2017) átfogó és öt ágazatra kiterjedő kutatási jelentése is igazolja.

${ }^{20}$ Lásd pl. Doppler, Lauterburg, 2014; Lauer, 2010.

${ }^{21}$ A nettó tőkeállomány $(K)$ nagysága az amortizációs kulcs $(\delta)$, az előző évi tőkeállomány nagysága $\left(K_{t-1}\right)$ és a táridőszaki beruházás $(B)$ függvénye. $K_{t}=(1-\delta) K_{t-1}+B_{t}$

${ }^{22}$ A Központi Statisztikai Hivatal részére készített kimutatások esetében (tekintettel arra, hogy a válla- 
lat valamelyik felső szintű vezetőjének kell azokat aláírnia) a tudatos csalások aránya alacsony, adatok tudatos torzítása csak a támogatások elszámolása kapcsán merülhet fel.

${ }^{23}$ A szervezeti megújulási képesség mérése a hazai vállalati gyakorlatban újszerủ, egyrészt a szerény magyar nyelvű szakirodalmi háttér (talán a kevés kivételek egyike Szabó és Csontos, 2016), másrészt a tulajdonosi elvárások hiánya miatt. A nemzetközi gyakorlatban ezzel szemben a szervezeti megújulást permanens, ciklikusan visszatérő feladatnak tekintik (Baumöl, 2008, p. 2; Kreitz, 2008).

${ }^{24} \mathrm{Az}$ értékteremtés fogalmát mind a makro-, mind pedig a vállalatgazdaság-tan régóta alkalmazza. Széles körű ismertsége Porternek köszönhető, aki elsők között tárgyalta az értéklánc kérdéskörét (Porter, 1980).

${ }^{25}$ A tulajdonosi érték a vállalati érték és a vállalat adósságállománya piaci értékének különbsége (Rappaport, 1986).

${ }^{26} \mathrm{Az}$ ISO-, EFQM-rendszert alkalmazó vállalatok esetében a fogalmak ismertek, számszerüsítik.

${ }^{27}$ A hozzáadott érték fogalma, számszerüsítésének módja a számviteli szakembereken túl a vállalati menedzsment körében is ismert (illetve ismerete elvárható); a témakör gazdag szakirodalommal rendelkezik. A számviteli szakterület minimálisan évente egyszer számszerűsíti és a szöveges beszámolóban értékeli.
${ }^{28}$ Az Alaptörvény 38. cikke rögzíti, hogy az állam és a helyi önkormányzatok tulajdona a nemzeti vagyon része. A Nemzeti vagyonról szóló 2011. évi CXCVI. törvény 9. \$ (1) bekezdése elöírja a helyi önkormányzatoknak, hogy közép- és hoszszú távú vagyongazdálkodási tervet kell készíteniük.

${ }^{29}$ Az MSZ ISO 55000: 2015 definíciója szerint: vagyongazdálkodás egy entitás (rendszer, szervezet) kapacitásának mértéke és adottsága arra, hogy elérje céljait (im.: p.13.).

${ }^{30}$ Környezeti terhelés: a vállalatnak a környezetre gyakorolt minden olyan hatása, amely károsan befolyásolja a környezet (vízbázis, talaj, légkör) állapotát.

${ }^{31}$ Ezek a szempontok jelennek meg az úgynevezett környezeti (környezeti vezetői, belső ökológiai, környezeti pénzügyi és külső ökológiai) számvitelben (Csutora, Kerekes, 2004; Schaltegger, Burritt, 2010; Hódi, Hernádi, 2012).

${ }^{32}$ A rövid távú haszonszemléletnek emiatt a környezetbarát technológiák és termékek fejlesztésének súlyos ára van, mint azt a vállalatok által előidézett környezeti katasztrófák sora igazolja.

${ }^{33}$ A témát a német szakirodalom Nachhaltigkeitsmanagements, az angol pedig Sustainability Management címen tárgyalja (részletesen lásd: Schaltegger et al., 2003).

IRODALOM

Adizes, I. (1990). Corporative Lifecycles. Englewood Cliffs, London

Aier, St., Dogan, T. (2005). Indikatoren zur Bewertung der Nachhaltigkeit von Unternehmensarchitekturen. pp. 607-626 In. Wirtstraftsinformatik,
Internationale Tagung Wirtschaftsinformatik. Physica-Verlag, Heidelberg, https://doi.org/10.1007/3-7908-1624-8_32

Anderson, W., Fonel, C., Lehmann, D. R. (1994). Customer Statisfaction, Market share and 
Profitabylity. Journal of Marketing, pp. 53-66, https://doi.org/10.2307/1252310

Báger G., Balogh G. (2010). Kompetenciaalapú struktúra kiépitésének lehetöségei a közigazgatásban. Állami Számvevőszék, Budapest

Bajmócy Z., Lengyel I., Málovics Gy. szerk. (2012). Regionális innovációs képesség, versenyképesség és fenntarthatóság. JATEPress, Szeged

BAUMöL, U. (2008). Change Management in Organisationen Situative Methodenkonstruktion für flexible Veränderungsprozesse. Gabler Verlag, Wiesbaden

Belitz, H., Eickelpasc, A., Le Mouel, M., Schiersch, A. (2017). Wissenbasiertes Kapital in Deutschland: Analyse zu Produktivizäts- und Wachstumeffekten und Erstellung eines Indikators. DIW, Berlin

BéLyácz I., Kovács K. (2017). Az eröforrásalapú vállalati növekedés testetlen eszköz komponensének növekvö szerepéröl. (in.: Bélyácz I. szerk.: A vállalati növekedés tapasztalatai az 1993-2012 közötti időszakban.) 107-131. oldal, Akadémiai Kiadó, Budapest

Birkmann, J., KoitKa, H., Kreibich, V., LIENENKAMP, R. (1999). Indikatoren für eine nachhaltige Raumentwicklung. Dortmunder Beiträge zur Raumplanung 96. Dortmund

Bostyn, F., Boytsun, A. eds. (2002). Ownership and Privatisation in Poland. Governance Implications of Poland's Accession to the European Union. Garanc, Antwerpen-Apeldoorn

Brown, L. R. (1981). Building a sustainable society. A World watch Institute book, W.W. Norton, New York, https://doi.org/10.1007/bf02712913
Carson, R. (1962). Silent Spring. Riverside Press, Boston, https://doi.org/10.1007/978-94-6209-068-2_5

Cucek, L., Klemes, J. J., Ktravanja, Z. (2012). Review of Footprint analysis tools for monitoring impacts on sustainability. Journal of Cleaner Production, Vol. 34, pp. 9-20, https://doi.org/10.1016/j.jclepro.2012.02.036

Csonka M., Kerekes S. (2004). A környezetbarát vállalatirányítás eszközei. KJK-Kerszöv, Budapest

Dietrich, I. (2012). Öffentliche Unternehmen in Deutschland. Eine Analyse von Mikrodaten der amtlichen Statistik. Universitätsverlag, Potsdam

Dirk, G. (2003). Herausforderung regional Nachhaltigkeit. Ökologisches Wirtschaftlen. Nr. 2. pp. 27-28, https://doi.org/10.14512/oew.v18i2.235

Dомокоs L. (2015). Átláthatóság, elszámoltathatóság, integritás - etikus közpénzügyi menedzsment három alapelve. Polgári Szemle, 11. évf. 4-6. szám

Domokos L., Várpalotai V., Jakovác K., Németh E., Makkai M., Horváth M. (2016). Szempontok az állammenedzsment megújításához. Pénzügyi Szemle, 2. szám 185-204. oldal

Doppler, K., Lauterburg, C. (2014). Change Management: den Unternehmenswandel gestolten. Campus Verlag, Frankfurt am Main

Gehrlein, U. (2004). Steuerung kommunaker Entwicklung und Nachhaltigkeitsindikatoren. Springer, Wiesbaden, https://doi.org/10.1007/978-3-322-97114-2_3

Hanke, S. H. (1987). Privatization versus $\mathrm{Na-}$ tionalization, in Prospects for Privatization. Steve H. 
Hanke, ed. Academy of Political Science, New York. pp. 1-3,

https://doi.org/10.2307/1174091

Hermen, A., Johnson, M. D. (1999). Die Kundenzufriedenheit als Bestimmungsfaktor der Kundenbindung. Zeitschrift für betriebswirtschaftliche Forschung. pp. 579-598, https://doi.org/10.1007/bf03371582

Hódi Hernádi, B. (2012). Green Accounting for Corporate Sustainability. Theory, Methodology, Practice, 8. (2), pp. 23-30

KereKes S., Jámbor I. szerk. (2012). Fenntartható fejlődés, élhető régió, élhető települési táj. Budapesti Corvinus Egyetem, Budapest

KocziszKy Gy. (1994). Adalékok a vállalkozások életgörbe elméletéhez. Vezetéstudomány, 25, (7) 12 20. oldal

KoczIszKy Gy. szerk. (2019). Etikus közgazdaságtan. Magyar Nemzeti Bank, Budapest

Kreitz, A. (2008). Optimale Organisation der Wertschöpfung internationaler Unternehmen. Modellhafta Abbildung und Vergleich organisatorischer Idealtypen. Rainer Hampp Verlag, München

Lauer, Th. (2010). Change Management-Grundlagen und Erfolgsfaktoren. Springer-Gabler Verlag, Wiesbaden

Meadows D. H., Meadows D. L., Randers J., Behrens W. W. (1972). The limits to growth. A report for the Club of Rome's project on the predicament of mankind. Universe Books. New York, https://doi.org/10.1349/ddlp.1

Meadows D. H., Meadows D. L. (1972). The Limits to Growth. Universe Books, New York
Megginson, W. L. (2005). The Financial Economics of Privatization. New York: Oxford University Press, https://doi.org/10.1093/0195150627.001.0001

Megginson, W. L., Jefrer M. N. (2003). History and Methods of Privatization, in International Handbook on Privatization. In.: Parkerm D. Saal D., eds. Cheltenham: Edward Elgar, pp. 25-40, https://doi.org/10.4337/9781781950951.00011

MıLıcz Á. (2016). Az állam piaci szerepvállalása és ellenőrzésének lehetőségei az állami tulajdonú gazdasági társaságoknál. Pénzügyi Szemle, Nr.2. 205228. oldal

Penrose, E. T. (1959). The Theory of the Growth of the Firm. Basil Blackwell, Oxford

Porter, M. E. (1980). Competitive Strategy Techniques for Analyzing Industries and Competitors. Free Press, New York

Porter, M. E., Linde, C. (1995). Toward a New Conception of the Einvironment-Comparativeness Relationship. Journal of Economics Perspectives, Nr. 4. pp. $97-118$,

https://doi.org/10.1257/jep.9.4.97

Rose-Ackerman, S. (1975). The Economics of Corruption. Journal of Public Economics, Vol. 4. pp. 187-203, https://doi.org/10.1016/0047-2727(75)90017-1

Salzmann, O., Ionescu-Somers, A., Steger, U. (2005). The business case for corporate sustainability: Literature review and research options. European Management Journal, 23 (I), pp. 27-36, https://doi.org/10.1016/j.emj.2004.12.007

Savas, E. S. (1987). Privatization: The Key to Better Government. Chatham House Publishers. New Yersey 
Schallhart, A. (2011). Integrale nachhaltigkeitsorientierte Unternehmensent-Wicklung. GRIN, Verlag, Norderstedt

SChaltegger S., Burritt R. (2010). Sustainability accounting for companies: Catchphrase or decision support for business leaders? Journal of World Business, 45. pp. 375-384, https://doi.org/10.1016/j.jwb.2009.08.002

Schalttegger, S., Kleiber, O., Müller, J. (2003). Die „Werkzeuge” des Nachhaltigkeitsmanagements. Konzepte und Instrumente zur Umsetzung unternehmerischer Nachhaltigkeit. (in.: Linne, G. et.al.: Handbuch Nachhaltige Entwicklung.) pp. 331-346, Springer Verlag, Wiesbaden, https://doi.org/10.1007/978-3-663-10272-4_31

SCHÖNEICH, M. (2001). Die öffentliche Wirtschaft in Deutschland. Bestandsaufnahme zu Beginn des 21. Jahrhunderts. Gesellschaft für öffentliche Wirtschaft, Berlin

Somogyi Z. (2013). A fenntarthatóság általános elmélete. Tézisek és hipotézisek a fenntarthatóságról. (Letöltve: 2019. 06. 08.), www.scienta.hu/fenntart hatosag/index.php

Stor, St. (2001). Der Staatats Unternehmer. Mohr Siebeck, Verlag, Heidelberg

Szabó Zs. R., Csontos R. (2016): Hatékony szervezeti megújulás: a technológia és menedzsment innovációk szerepe. Vezetéstudomány, Nr. 1. 31-35. oldal

SZLÁvik J. (2013). Fenntartható gazdálkodás. Complex, Budapest

Veresné Somosi M. (2005). A munkatársak irányítása és elégedettsége a szervezeti önértékelésen keresztül. Harvard Businessmanager, 2005.Nr. 11
DU (2004). Indikatoren-Set „Zukunftsfähige Kommune". Deutsche Umwelthilfe e.v; Radolfzell. https://doi.org/10.1002/9783527678471.hbnl2004008

EC (2002). Key Competencies. A developing concept in general comulsory education. European Comission DG for Education and Culture

ECD (2001). Definition and Selection of Competencies: Theoretic and Conceptual Foundation (DeSeCo). Background Paper, Paris

ÉMSZB (2018). Fenntartható település modellek (10.000 fô feletti települések számára). Építésügyi Műszaki Szabályozási Bizottság, Szentendre

MNB (2019). Módszertani leírás. Az állami és önkormányzati tulajdonú, nem az államháztartásba sorolt (közösségi, public) vállalatok éves pénzügyi számláinak adatközléséhez. (Letöltés ideje: 2019. 07. 01.), www.mnb.hu/letoltes/modszertan-kozos

MSZ (2015a). Vagyongazdálkodás. Áttekintés, alapelvek és terminológia. MSZ ISO 55000. Magyar Szabványügyi Testület, 2015. július

MSZ (2015b). Vagyongazdálkodás. Irányítási rendszerek. MSZ ISO 55001. Követelmények. Magyar Szabványügyi Testület, 2015. július

OECD (2013a). Supparting Investment in Knowledge Capital, Growth and Innovation. OECD, Paris.

https://doi.org/10.1787/9789264193307-sum-en

OECD (2013b). New Sources of Growth: Knowlogde-Based Capital-Key Analysis and Policy Conclusions. OECD, Paris

Rió (1993). A Riói Nyilatkozat a Környezet és Fejlődésről. Az ENSZ Környezet és Fejlődés Világkonferencia Dokumentumai. Föld Napja Alapítvány, Budapest 
FÓKUSZ - A TELJESÍTMÉNY MÉRÉSE ÉS MENEDZSELÉSE A KÖZSZFÉRÁBAN

UNEP (2011). Global Environmental Outlook 5, Nairobi

United Nations (2011). Sustainable development in the 21st century: implementation of Agenda 21 and the Rio principles, detailed report on the imple- mentation of Agenda 21, Department of Economic and Social Affairs, New York

United Nations (2012). United Nations Conference on Sustainable Development Outcome Document: The future we want. A/CONF.216/L.1. 